\title{
A Miocene onset of the modern extensional regime in the Isparta Angle: constraints from the Yalvaç Basin (southwest Turkey)
}

\author{
Ayten Koç • Nuretdin Kaymakci • \\ Douwe J. J. van Hinsbergen • Reinoud L. M. Vissers
}

Received: 2 May 2014 / Accepted: 31 October 2014 / Published online: 21 November 2014

(C) Springer-Verlag Berlin Heidelberg 2014

\begin{abstract}
The pre-Neogene Tauride fold-and-thrust belt, comprising Cretaceous ophiolites and metamorphic rocks and non-metamorphic carbonate thrust slices in southern Turkey, is flanked and overlain by Neogene sedimentary basins. These include poorly studied intra-montane basins including the Yalvaç Basin. In this paper, we study the stratigraphy, sedimentology and structure of the Yalvaç Basin, which has a Middle Miocene and younger stratigraphy. Our results show that the basin formed as a result of multi-directional extension, with NE-SW to E-W extension dominating over subordinate NW-SE to N-S extension. We show that faults bounding the modern basin also governed basin formation, with proximal facies close to the basin margins grading upwards and basinwards into lacustrine deposits representing the local depocentre. The Yalvac Basin was a local basin, but a similar, contemporaneous history recently reconstructed from the Altınapa Basin, $\sim 100 \mathrm{~km}$ to the south, shows that multi-directional extension dominated by E-W extension was a regional phenomenon. Extension is still active today, and we conclude that
\end{abstract}

Electronic supplementary material The online version of this article (doi:10.1007/s00531-014-1100-z) contains supplementary material, which is available to authorized users.

A. Koç $(\bowtie) \cdot$ D. J. J. van Hinsbergen · R. L. M. Vissers Department of Earth Sciences, Utrecht University,

3508 TA Utrecht, The Netherlands

e-mail: a.koc@uu.nl

\author{
A. Koç \\ Department of Geological Engineering, Yüzüncü Yıl University, \\ Van 65080, Turkey \\ N. Kaymakci \\ Department of Geological Engineering, Middle East Technical \\ University, Ankara 06531, Turkey
}

this tectonic regime in the study area has prevailed since Middle Miocene times. Previously documented E-W shortening in the Isparta Angle along the Aksu Thrust, 100 km to the southwest of our study area, is synchronous with the extensional history documented here, and E-W extension to its east shows that Anatolian westwards push is likely not the cause. Synchronous E-W shortening in the heart and E-W extension in the east of the Isparta Angle may be explained by an eastwards-dipping subduction zone previously documented with seismic tomography and earthquake hypocentres. We suggest that this slab surfaces along the Aksu thrust and creates E-W overriding plate extension in the east of the Isparta Angle. Neogene and modern Anatolian geodynamics may thus have been driven by an Aegean, Antalya and Cyprus slab segment that each had their own specific evolution.

Keywords Yalvaç Basin · Paleostress inversion · Kinematics · Central Taurides · Anatolia · Geodynamics

\section{Introduction}

Intense deformation in Anatolia occurred in the context of long-lived and still ongoing convergence between Africa and Eurasia. Today, Anatolia is located in the overriding plate of a complex subduction system with bow-like trenches forming the Aegean-west Anatolian, and Cyprus 'arcs'. The Isparta Angle (IA), a triangular-shaped complex tectonic structure defined firstly by Blumenthal (1963), constitutes the junction between the Cyprus and Aegean Arcs (Fig. 1a, b). The Isparta Angle contains shortened Mesozoic units and ophiolites that were thrust and stacked in Late Cretaceous to Miocene times, with opposing thrust vergences. The deepest tectonostratigraphic unit is the Bey 
Dağları carbonate platform and is overthrusted from the NW by the Lycian Nappes, a composite nappe system of ophiolites and Mesozoic sediments that underwent its final emplacement over the Bey Dağları foreland in the Early Miocene (Hayward 1984; Okay 1989; Collins and Robertson 1997, 1998, 2003; van Hinsbergen 2010). From the east, the Bey Dağları platform is also overthrust by ophiolite- and carbonate-dominated thrust sheets known as the Antalya Nappes. The youngest thrusting at the contact with Bey Dağları-Western Taurides-occurred in the Early Miocene time (Hayward 1984) whilst Middle Miocene to Pliocene out-of-sequence thrusting in the Isparta Angle is dominated by the Aksu Thrust and the Kurkkavak strikeslip and normal-dominated fault (Dumont and Kerey 1975; Glover and Robertson 1998; Poisson et al. 2003; Deynoux et al. 2005; Flecker et al. 2005; Çiner et al. 2008; Schildgen et al. 2012a) and their offshore equivalents in the Bay of Antalya (Hall et al. 2014) (Fig. 1).

Despite the long and intense history of shortening, the present-day tectonic regime as portrayed by active seismicity, earthquake focal mechanisms, field data, including fault plane solutions, and GPS measurements shows that the northern and eastern part of the Isparta Angle experience extension. At depths beyond $50 \mathrm{~km}$ below the Isparta Angle, however, an east-dipping slab segment is imaged by seismic tomography (de Boorder et al. 1998; Biryol et al. 2011), which is still accommodating E-W compression as shown by earthquake solutions (Schildgen et al. 2012a). Seismicity shows active deformation along the AkşehirAfyon Fault Zone, the Ilgın Fault Zone, the Yaka-Eğirdir Fault Zone and the Konya Fault Zone (Fig. 2). Focal mechanism solutions of moderate-size earthquakes along these faults in historic times indicate regionally multi-directional extension, with range-bounding major normal faults accommodating dip-slip NE-SW extension that occur in tandem with NW-SE extension accommodated along less prominent fault zones (Taymaz et al. 2004; Ergin et al. 2009; Poyraz et al. 2014; Tiryakioğlu et al. 2013; Koçyiğit et al. 2012) (Fig. 2).

Both the Miocene to Pliocene E-W to NE-SW shortening in the heart of the Isparta Angle, and the present-day $\mathrm{NE}-\mathrm{SW}$ extension that governs the range-bounding normal faults in the north-eastern flank of the Isparta Angle are not straightforwardly explained in a context of $\sim \mathrm{N}-\mathrm{S}$ AfricaEurasia convergence. Previous workers have focused especially on the shortening accommodated along the Aksu Thrust and postulated a causal relationship with westwards Anatolian escape (e.g. Glover and Robertson 1998; Deynoux et al. 2005; Hall et al. 2014). Westwards motion of Anatolia relative to Eurasia, accommodated along the major North Anatolian Fault Zone, is prominent in GPS measurements (e.g. McClusky et al. 2000; Reilinger et al. 2010) and is believed to have started around $11 \mathrm{Ma}$
Fig. 1 (a) Simplified structural map of southern Turkey overlain on an SRTM topographic image. White rectangle denotes area shown in $(c),(b)$ major tectonic zones of Turkey (modified from Okay et al. 1996 and Kaymakci et al. 2010. (c) Simplified geological map of the Isparta Angle showing location of the study area (red rectangle)

in response to Arabia-Eurasia collision in eastern Turkey (e.g. Şengör et al. 2003; Faccenna et al. 2006; Hüsing et al. 2009; Okay et al. 2010).

Less attention has been given to the Cenozoic kinematic history of the eastern limb of the Isparta Angle. Active and fossil normal faults in the northern and eastern part of the Isparta Angle border Neogene sedimentary basins (Fig. 1c). Whereas high on the Tauride mountains, relict extensional basins are found with upper Miocene marine sediments (Deynoux et al. 2005; Cosentino et al. 2012; Schildgen et al. 2012a), basins flanking the Tauride mountains to the east are filled by continental sediments and in places volcanics, and formed in an overriding plate setting of the present-day Cyprus subduction zone, as well as above the Antalya slab fragment. These intramontane basins include the Altınapa, Ilgın (or Akşehir) and Yalvaç Basins (Fig. 1c), which have basin in-fill that started to accumulate in the Miocene (Göğer and Kıral 1969; Özcan et al. 1990; Yağmurlu 1991a, b; Eren 1993, 1996; Özkan 1998; Özkan and Söğüt 1999; Koç et al. 2012) (Fig. 1a).

To assess the geodynamic causes governing the active deformation in south-western Turkey, it is key to obtain information for the temporal relationships between regional extension and compression directions as well as geometry, stratigraphy and facies associations and evolutionary history of the basins in the region. In this paper, we study the geological evolution of the Yalvac Basin, a $15 \mathrm{~km}$ wide, $55 \mathrm{~km}$ long, NNW-SSE trending intra-montane basin located in the northern tip of the Isparta Angle, to assess its kinematic history and inception age of active tectonics in the region in the context of the development of the Isparta Angle. To this end, we studied sedimentary and stratigraphic records in the Yalvaç Basin. In addition, the structural and kinematic evolution of the basin is also studied using remotely sensed data and field mapping to understand the interplay between tectonics and sedimentation in the basin as well as temporal relationships between basin-infill and mapped structures in the region. In order to determine the timing of tectonic events, the stratigraphic data are integrated with the kinematic data. In this regard, especially the growth faults and syn-depositional structures provided the most reliable information for correlation and reconstructing the temporal relationships between faults and the dating of the paleostress inversion-based deformation phases (c.f. Angelier 1994) that prevailed in the region since the Middle Miocene. 

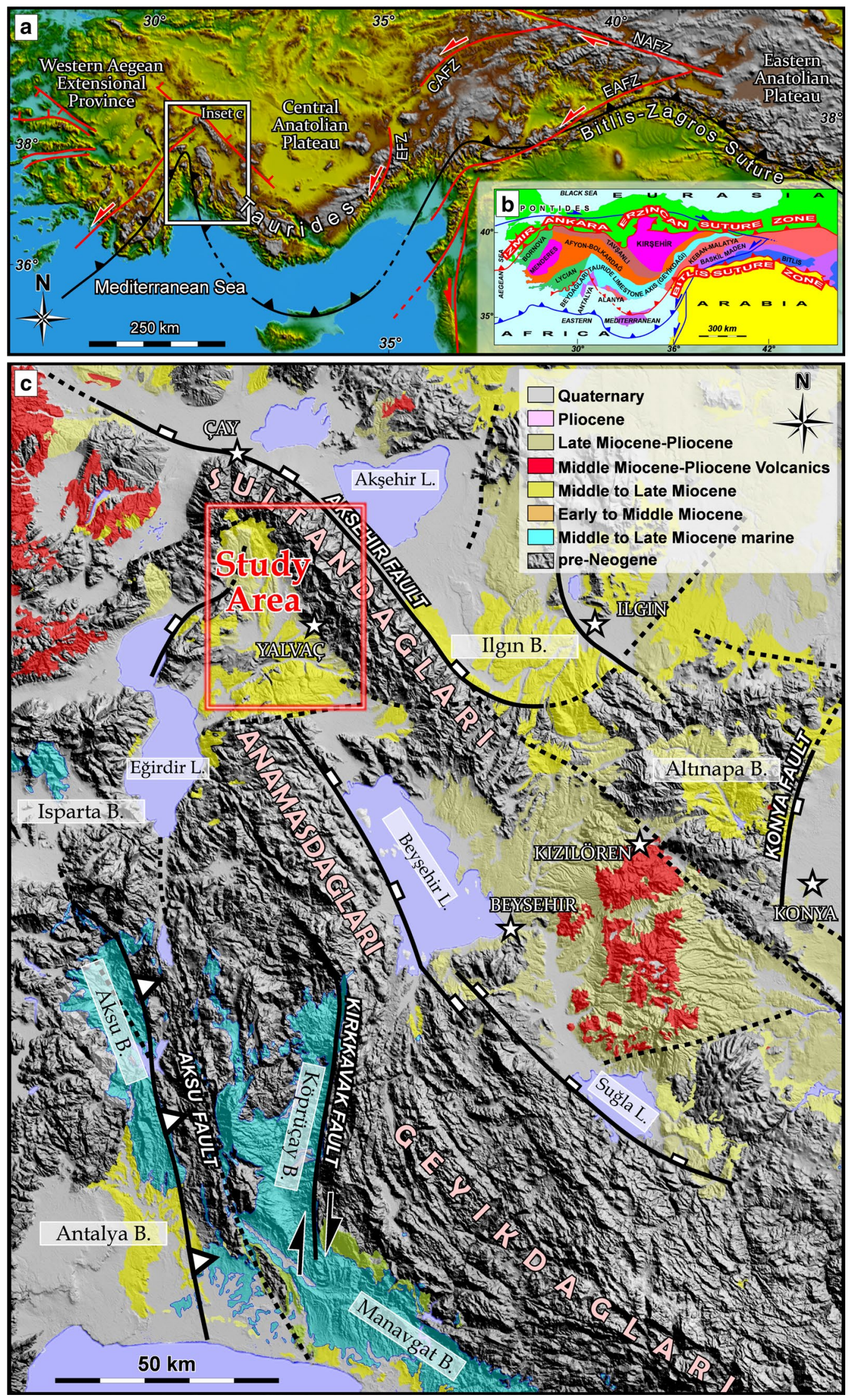


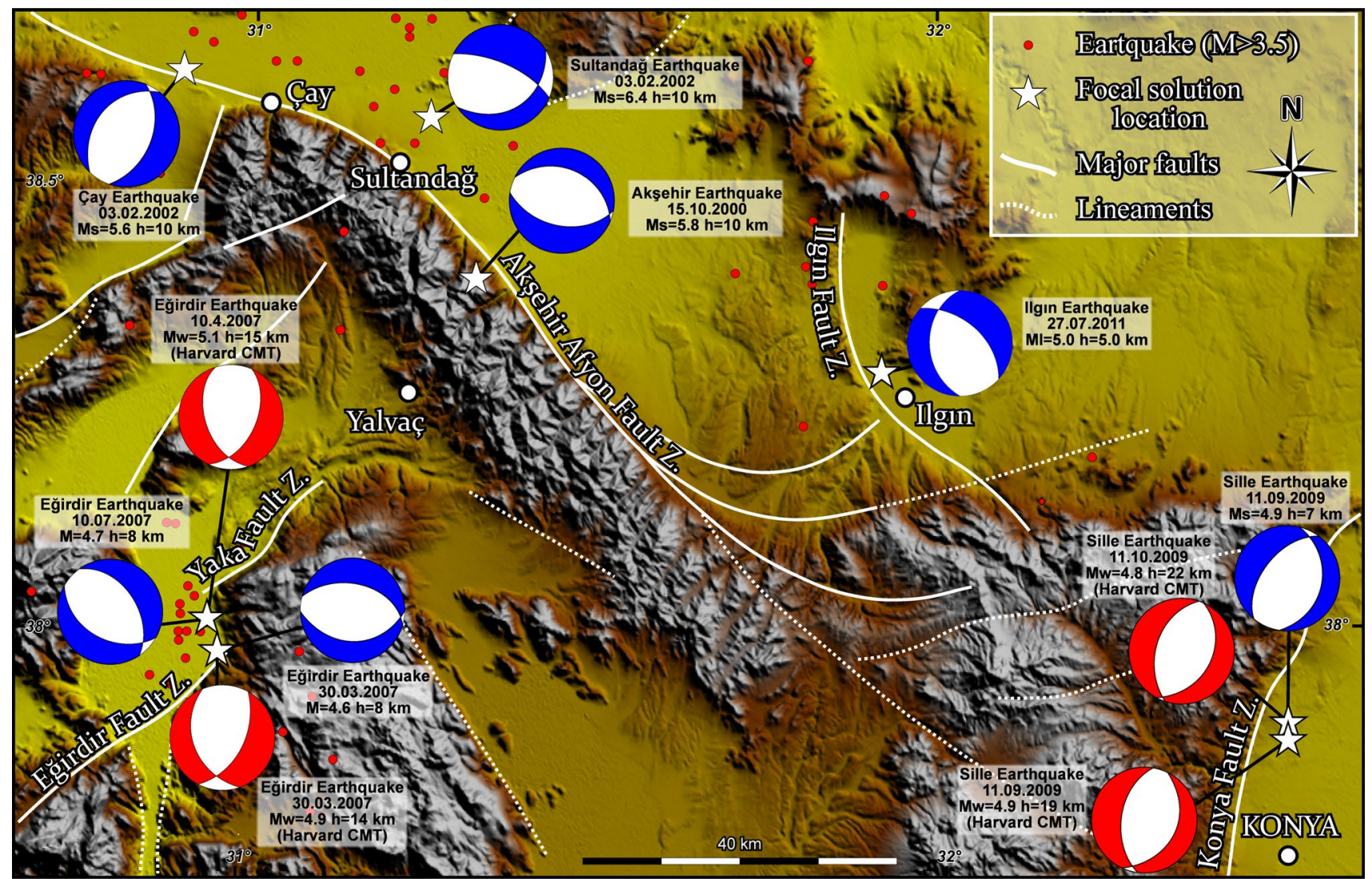

Fig. 2 Major structures of the region shown on a shaded relief image, with moment tensor solutions of recent major earthquakes $(\mathrm{M}>3.5)$. Beachballs with red show focal mechanism solutions from Harvard global CMT catolog, and beachballs with blue indicate focal mechanism solutions from Ergin et al. (2009), Taymaz et al. (2004), Poyraz et al. (2014), ERD and ETHZ catalog. Label for earthquake mechanism indicates date, magnitude and hypocentre depth

\section{Geology of the Yalvaç Basin}

The Yalvaç Basin is located in the northern part of the Isparta Angle. It comprises a continental succession bounded in the north, west and east, and overlying basement highs comprising folded and thrust (meta-) sediments ranging in age from Ordovician to Cretaceous as well as presumably Cretaceous ophiolitic rocks (Yağmurlu 1991a). Thrusting within the Tauride nappes continued into the Eocene (Altıner et al. 1999; Andrew and Robertson 2002), and the Yalvaç basin unconformably overlies this nappe system. In this paper, we summarize the key characteristics of the stratigraphy, structure, and sedimentology of the basin and show a selection of field photographs to illustrate and exemplify these descriptions.

\section{Lithostratigraphy and sedimentology}

The first geological studies on the $>800$-m-thick (Yağmurlu 1991a, b) stratigraphy of the Yalvaç Basin concentrated mainly on lignite-bearing Neogene units (Lahn 1940; Wedding 1954; Fürst 1955; Göktunalı 1957; Pekmezciler 1958) to evaluate the lignite content of the region. Yağmurlu (1991a) established a more detailed Neogene stratigraphy of the basin and formalized the stratigraphy. We adopt the formation nomenclature of Yağmurlu (1991a) and divide the Neogene lithostratigraphy into four main stratigraphic units, from older to younger (1) the Bağkonak Formation, (2) the Yarkkkaya Formation, (3) the Göksöğgut Formation and (4) the Kurkbaş Formation (Fig. 3). Below, we describe their lithology, age and contact relationships and provide an interpretation of their depositional environments (Figs. 3, 4).

\section{Bağkonak Formation}

The Bağkonak Formation (Demirkol 1982; Yağmurlu 1991a) contains $250 \mathrm{~m}$ of continental red clastics with dominantly conglomerates at the bottom and intercalating sandstone and sandy-mudstone towards the upper levels. The unit is well-exposed around Özbayat and Bağkonak located 


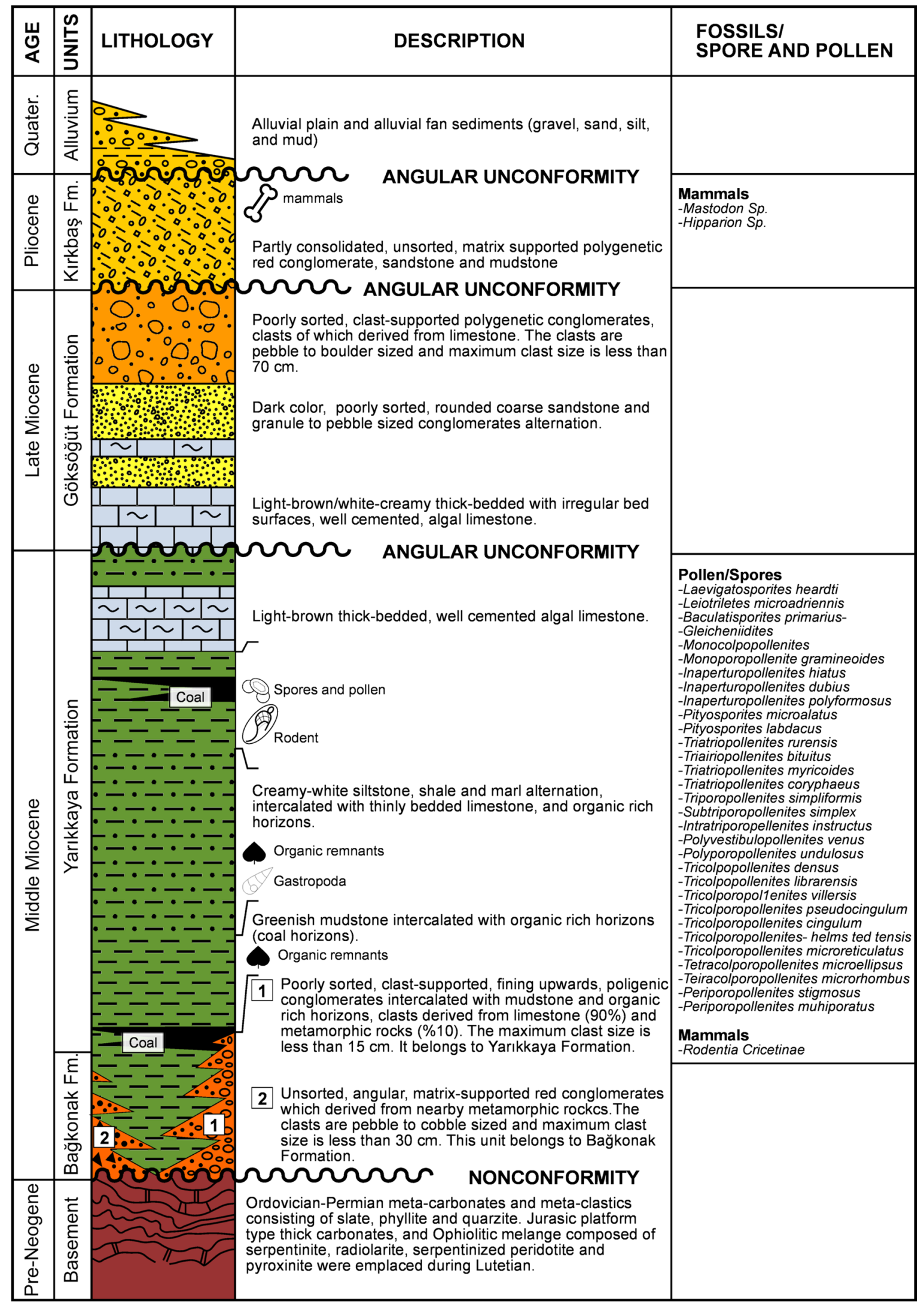

Fig. 3 Generalized stratigraphic column for the Yalvaç Basin 


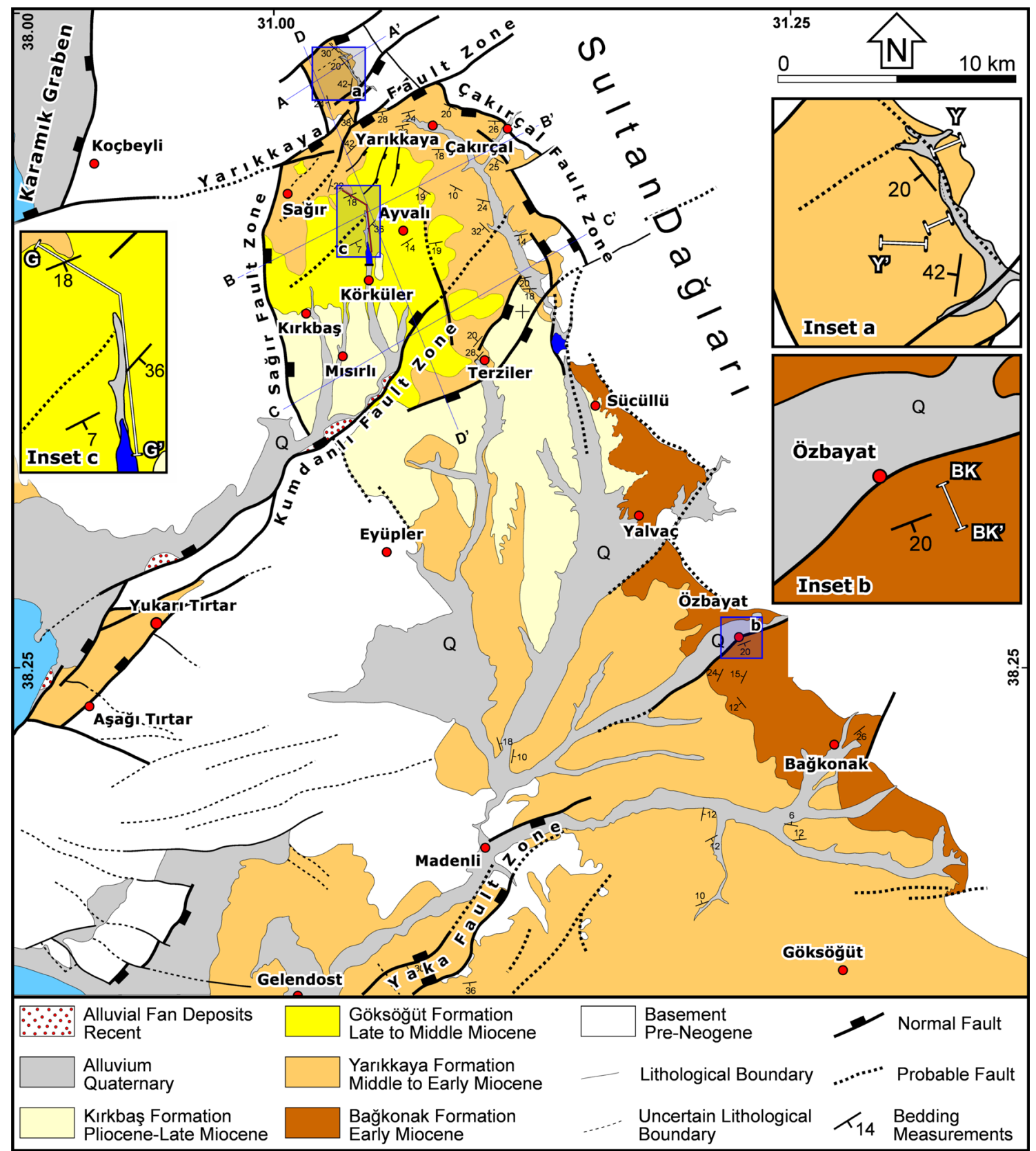

Fig. 4 Geological map of the study area based on field observations and remotely sensed data in this study. Blue rectangles denote locations of lithological sections, with inset map (a) for the Göksögüut Formation (Göksöğüt Formation), (b) for the Yarıkkaya Forma- tion (Yarkkkaya Formation) and $(c)$ for the Bağkonak Formation (Bağkonak Formation). Sections on the inset maps are indicated by white solid lines $\left(\mathrm{G}-\mathrm{G}^{\prime}\right.$ for Göksöğ̈ut Formation, $\mathrm{Y}-\mathrm{Y}^{\prime}$ for Yarıkkaya Formation and $\mathrm{BK}-\mathrm{BK}^{\prime}$ for Bağkonak Formation) to the south of Yalvaç (Fig. 4), where we documented the type section of the Bağkonak Formation (Fig. 5). The formation unconformably overlies pre-Neogene units, exposed in an erosional window near Bağkonak, that include lowgrade metamorphic rocks and carbonates, and grades vertically and basinwards into yellowish/white marly deposits of the Yarıkkaya Formation.
We measured a section in the Bağkonak Formation (Fig. 5) south of Özbayat, where a 130-m-thick succession starts at the bottom with angular, unsorted, clast-supported, well-cemented, $10 \mathrm{~cm}$ - to 2-m-thick-bedded reddish conglomerates. Pebbles of the conglomerates ranging from gravel to boulder size (up to $50 \mathrm{~cm}$ in diameter), comprise slightly foliated green metamorphic rocks $(90 \%)$ and light 

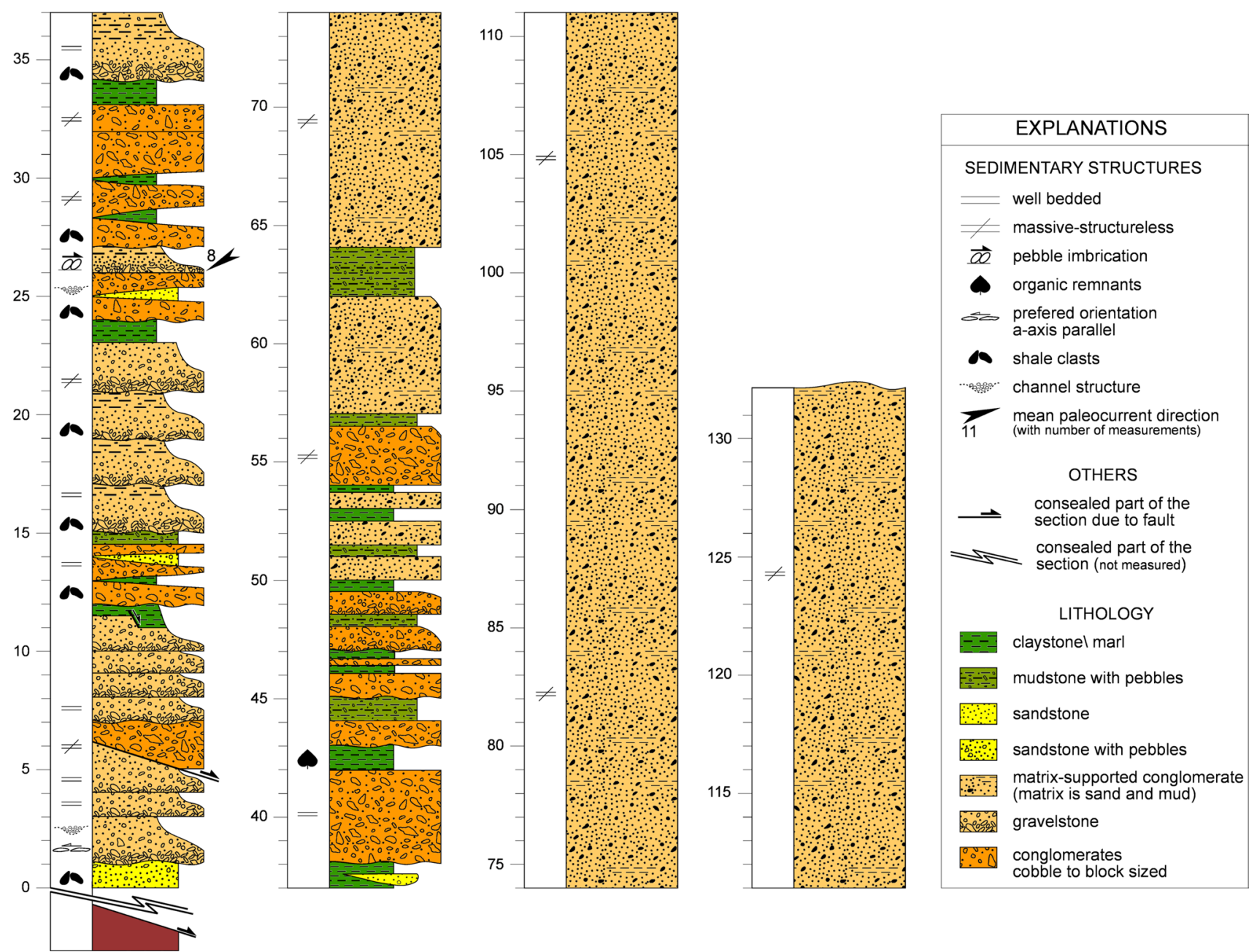

Fig. 5 Lithological section of the Bağkonak Formation. For location of the section see Fig. 4

to dark grey carbonates $(10 \%)$, exposed in the nearby Sultandağları Mountain (Fig. 6a). The arrangement of the pebbles is generally chaotic suggesting rapid sedimentation, whereas finer beds are fining upwards. Towards the upper parts, the conglomerates become gradually matrix supported. Sedimentary structures such as pebble imbrications and scour-and-fill structures (channel deposits) are occasionally observed. Cannibalization of basin sediments is shown by erosional bases of channels and abundant shale clasts in the lower parts of the conglomerate beds. Upwards, brick red to purple sandstones and sandy mudstones alternate with conglomerates. The top of the section contains $\sim 70 \mathrm{~m}$ of monotonous matrix-supported polygenic conglomerates. The pebble $(<5 \mathrm{~cm})$ clasts are dispersed in a poorly sorted matrix of sand and silt.

We interpret the unsorted, angular and boulder to pebble, reddish/brownish conglomerates in the lower part of the Bağkonak Formation as an indication of proximity to the sediment source. Upwards grading and basal erosion of conglomerate lenses signify an energetic environment and the poor sorting, and overall fining-upwards character of the upper part of the unit suggests an origin as gravity flows with sediment transported in turbulent suspension. Hence, the Bağkonak Formation was probably deposited as debris flows in alluvial fans and bird-foot deltas along the basin margin formed by the Sultandağları range.

Neither this nor previous studies (Demirkol 1982; Yağmurlu 1991a) of the Bağkonak Formation have yielded any fossils. The interfingering Yarıkkaya Formation, however, was inferred to be Middle Miocene in age (see below).

\section{Yarıkkaya Formation}

The Yarlkkaya Formation is composed of coarse, subrounded, poorly sorted, grain-supported conglomerates at the bottom and grades upwards into sandstone and coarsens towards the top with boulder to block, subangular, matrix- and grain-supported conglomerates. We 

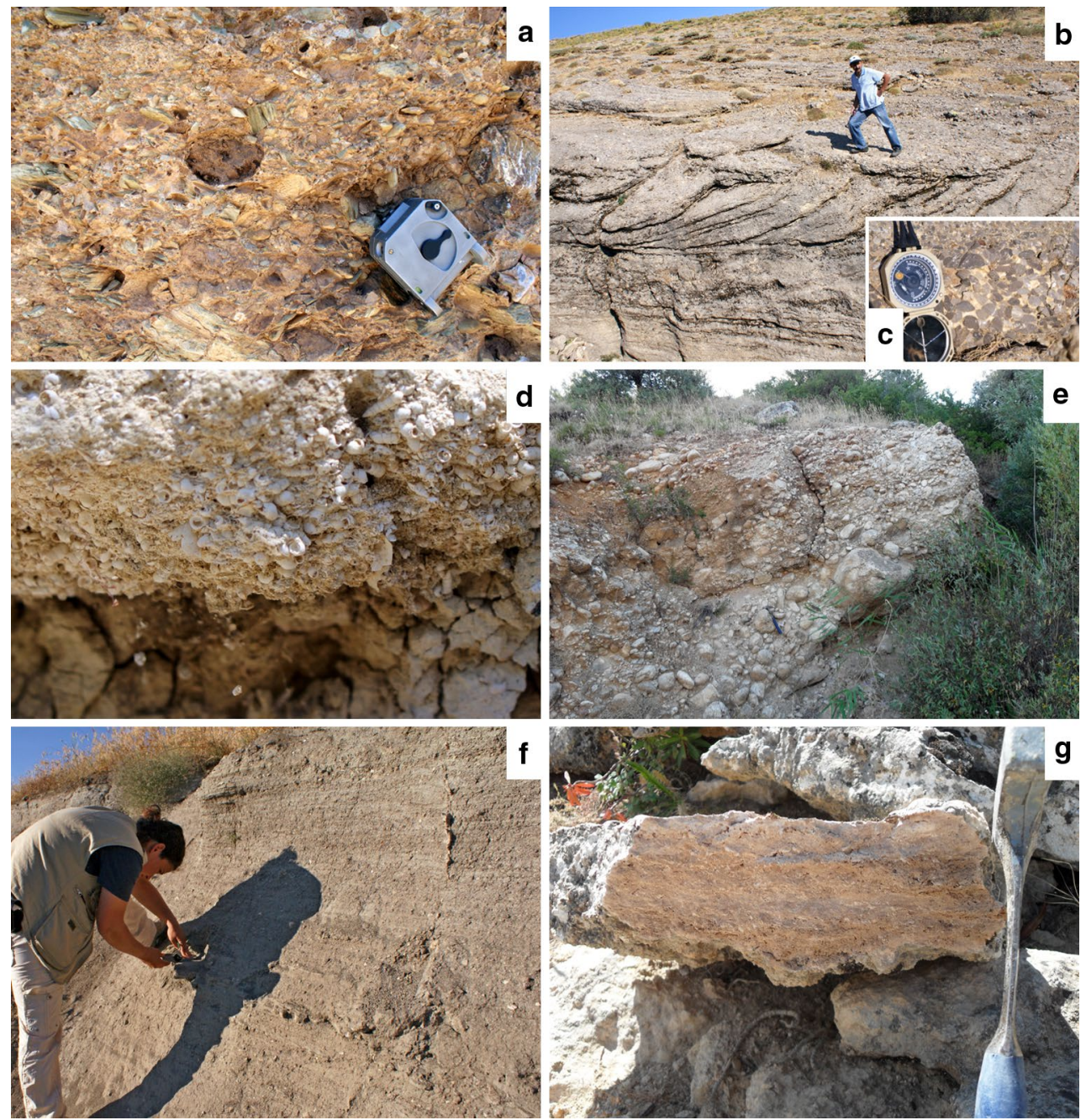

Fig. 6 Close-up view of the lithologies observed in the Yalvaç Basin. a Basal conglomerate of the Bağkonak Formation around the Bağkonak, b cross-bedding in the conglomerates is observed in the lower part of the Yarıkkaya Formation around and north of Yarıkkaya, c view of the conglomerates in the lower part of the Yarıkaya For-

studied two sections of the Yarıkkaya Formation close to Yarıkkaya (Fig. 4). The formation unconformably overlies pre-Neogene units including low-grade metamorphic rocks and carbonates in the north and conformably overlies the Bağkonak Formation in the south. It is overlain by the Göksöğüt Formation, unconformably in the north and conformably in the south.

We constructed a composite section of the Yarıkkaya Formation based on two different locations, separated by the Yarıkkaya Normal Fault, representing a proximal and a more distal equivalent of the formation (Fig. 7a). The proximal part of the section is $\sim 400 \mathrm{~m}$ thick and has been studied $\sim 4 \mathrm{~km}$ north of Yarıkkaya, where a basal conglomeratic unit overlying pre-Neogene basement is exposed. The succession starts with sub-rounded, unsorted, well-cemented mation, d gastropod-rich level in the Yarıkkaya Formation, e blocky, poorly sorted, sub-angular to sub-rounded conglomerates of the Göksögüt Formation, f sandstone level in the Göksöğüt Formation, $\mathbf{g}$ banded and porous, possibly lacustrine algal limestone in the Göksöğüt Formation

and medium- to thick-bedded $(30-40 \mathrm{~cm})$ polygenic conglomerates (Fig. 6b, c), overlying carbonates and low-grade metamorphic rocks of the Sultandağları Mountain. Clasts of the conglomerates ranging from pebble to cobble size (up to $20 \mathrm{~cm}$ in diameter) comprise light to dark grey limestone $(95 \%)$ and green metamorphic rocks $(5 \%)$. Pebbles are randomly arranged, and pressure solution pits are occasionally observed at pebble contacts, suggesting significant compaction. Most conglomerate beds are graded and display imbrication and cross-bedding (Fig. 6b). In the middle parts, the section comprises thin- to mediumbedded $(<30 \mathrm{~cm})$, green/blue organic-rich mudstone and white marls alternating with conglomerates and sandstones. The succession continues upwards with coarse, subangular to sub-rounded, unsorted, occasionally grain- or 


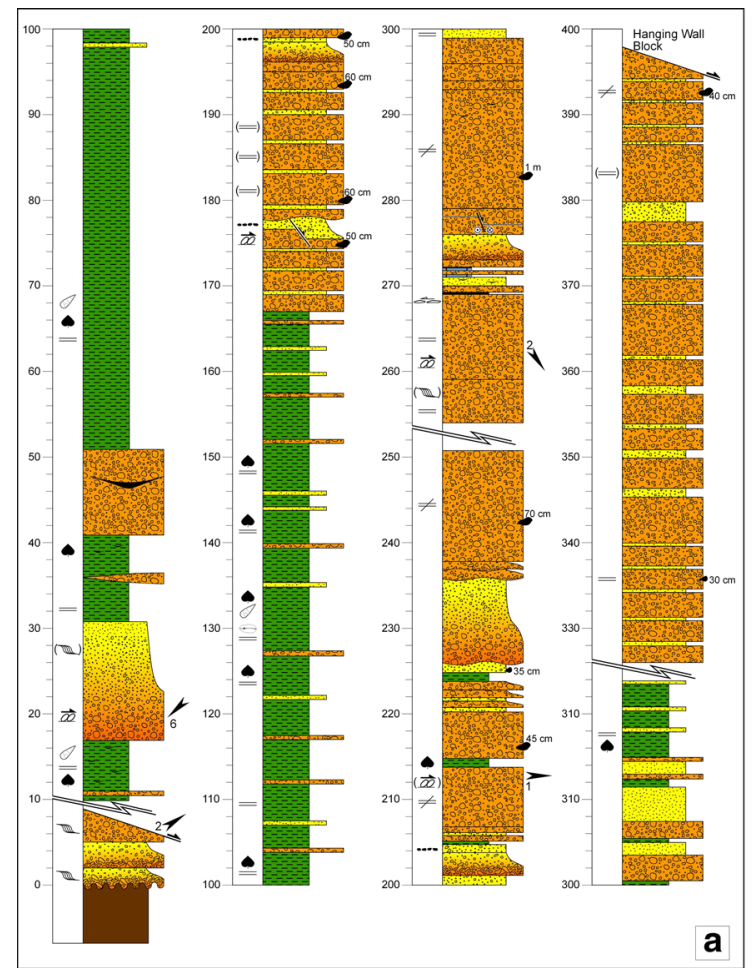

a
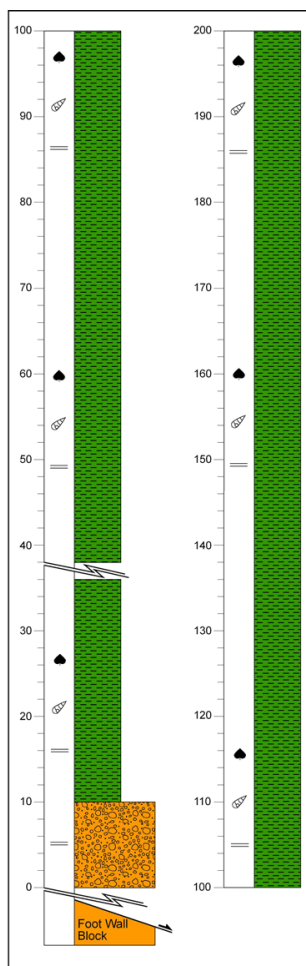

EXPLANATIONS

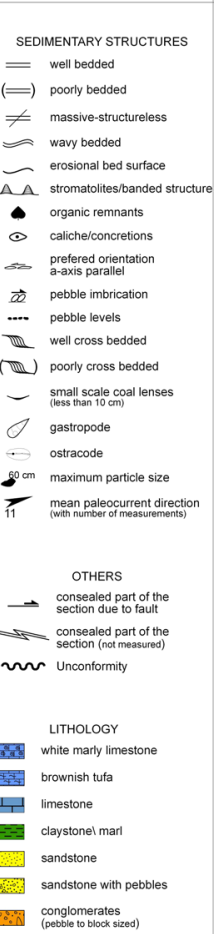

Fig. 7 a Columnar section of the lower part of the Yarıkkaya Formation, taken in the footwall block of the Yarıkkaya Fault Zone, b columnar section of the upper level of the Yarıkkaya Formation (in the hanging-wall block of the Yarıkkaya Fault Zone). For locations of sections see Fig. 4, inset map b matrix-supported, polygenic conglomerates alternating with sandstone. Clasts of the conglomerates range from pebbles to block size $(15 \mathrm{~cm}-1 \mathrm{~m})$ comprising light to dark limestone and green, slightly foliated metamorphic rocks. At these levels, cross-bedding and pebble imbrication are occasionally observed.

The distal section, located in the hanging wall of the Yarıkkaya Normal Fault, is $\sim 400 \mathrm{~m}$ thick and likely represents a lateral equivalent of the section in the footwall (Fig. 7b). This section is located $\sim 3 \mathrm{~km}$ northwest of Yarıkkaya and exposes tufa, lacustrine marly limestone and conglomerate units. The succession starts with coarse (sub)-angular, well-cemented and clast-supported conglomerates overlying the carbonate basement. Conglomerate clasts range from pebble to boulder size (up to $30 \mathrm{~cm}$ ) and consist mostly of limestones ( $>95 \%$ ) probably originating from the underlying carbonate basement. The succession continues upwards with creamy-white marl/claystone containing freshwater gastropods (Fig. 6d) and fossil leaves. This is followed by a green mudstone and lignite seams that are mined. Upwards, white fossiliferous marly limestones and banded, undulated, highly porous tufas alternate with medium- to thick-bedded, poorly sorted clast-supported conglomerates and cross-bedded yellowish sandstones. Clasts of the conglomerates are well rounded and comprise $>95 \%$ light to dark grey limestone.
Yağmurlu (1991a) reported freshwater fossils in the mudstone and claystone levels of the Yarıkkaya Formation, including Planorbis sp. and Limnea sp. as well as pollen and spore assemblages, and inferred a Middle Miocene age. Saraç (2003) suggested an Early-Middle Miocene age based on fossil vertebrates Rodentia-Cricetinae from lacustrine deposits in the upper part of the Yarkkkaya Formation.

We interpret the boulder to block, sub-angular to subrounded, matrix- and grain-supported conglomerates with cross-bedding and pebble imbrications in the lower part of Yarıkkaya Formation as deposited in a fluvial environment. The fine mud/clay, marly limestone and tufa deposits towards the basin centre are interpreted as shallow lacustrine deposits with intercalation of fluvial conglomerates and sandstones representing relative lake-level variations. Lignite seams are interpreted as swamp deposits. The Yarıkkaya Formation and the Bağkonak Formation thus show a gradual transition from alluvial aprons along the basin margin, through low-sinuosity streams to lacustrine facies in the central parts of the basin.

\section{Göksöğüt Formation}

The Göksögüt Formation is composed of banded, highly porous brownish limestone at the base and coarsens 


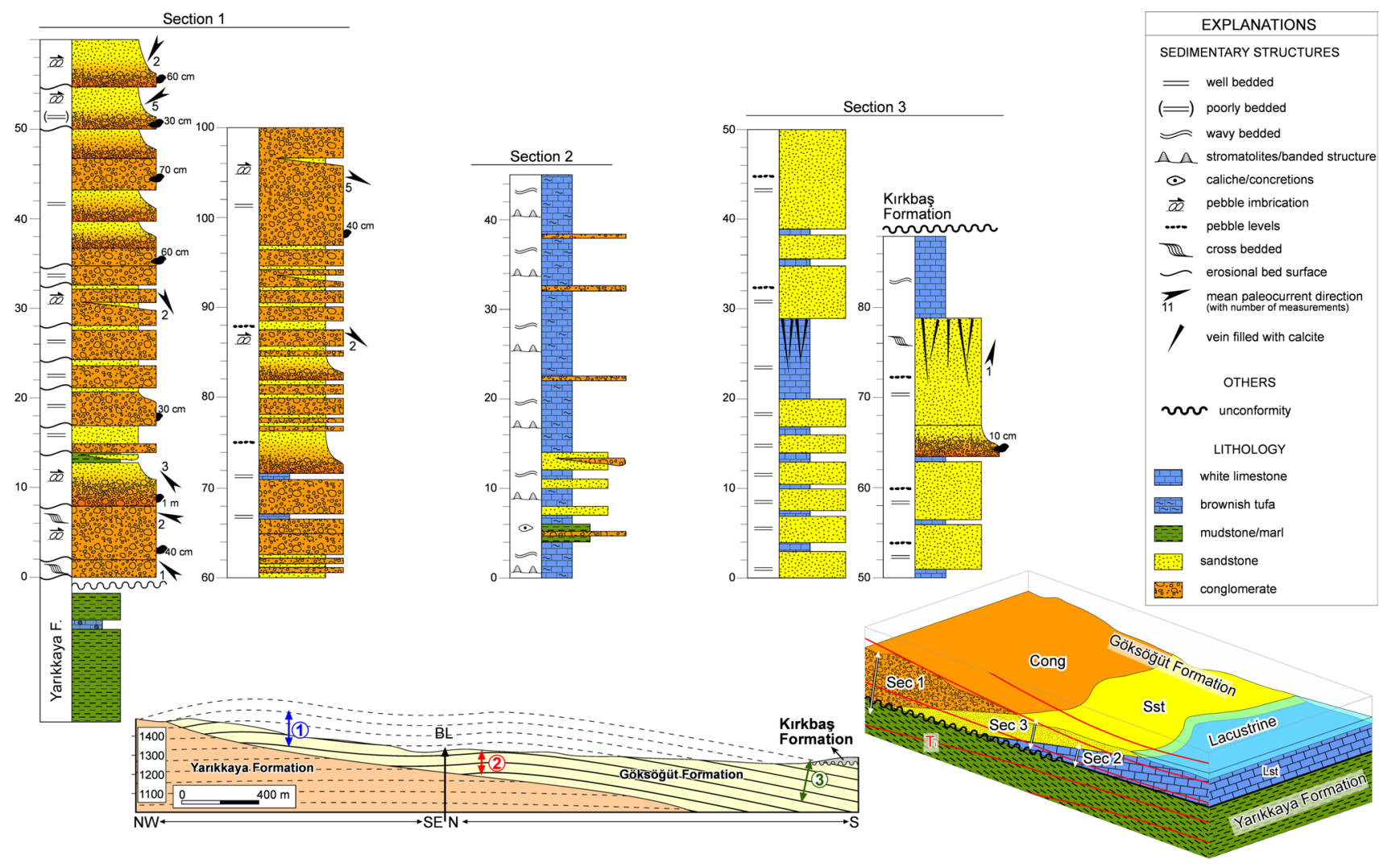

Fig. 8 Columnar sections of the Göksöğüt Formation, with their relative positions shown in the cross section and block diagram. The location of the cross-sectional line is given in Fig. 4, inset map $a$. In the cross section, BL refers to breaking point of the section orienta-

upwards into rounded, poorly sorted, grain-supported conglomerates. The formation grades laterally, from north to south, into black sandstone and algal limestone. The formation is well-exposed north of Körküler and around Ayvalı where we analysed a section of the Göksöğüt Formation in detail (Fig. 8). It overlies the Yarıkkaya Formation and is unconformably overlain by the Kırkbaş Formation.

The Göksöğüt section is at least $150 \mathrm{~m}$ thick and was studied in three locations north of Körküler (Fig. 8). The base of the unit contains of $\sim 45 \mathrm{~m}$ banded, porous, buff to brownish limestone (Fig. 6g), intercalated with rounded, unsorted pebble to cobble (up to $7 \mathrm{~cm}$ in diameter) matrixsupported conglomerates and coarse sandstones with floating pebbles. Clasts of the conglomerates consist mostly of limestones ( $>95 \%$ ) (Fig. 6e) and are set in a carbonate matrix. As a result, these conglomerates appear as massive limestone in outcrop. Upwards, thick bedded, unsorted, angular to rounded grain-supported conglomerates appear (Fig. 6e). Clasts range from pebble to block (up to $1 \mathrm{~m}$ ) and consist of light to dark grey limestone (>95\%) and occasionally green metamorphic rock. Sedimentary structures such as pebble imbrications, cross-bedding, channels and erosion surfaces at the base of the bedforms (scour-and-fill tion. The block diagram indicates the lithological boundaries. Red lines in the block diagram denote time lines (Ti) during deposition. Note that the shoreline migrates towards the lacustrine side (i.e. it is a regressional system)

structures) were occasionally observed. Around Ayvalı, these conglomeratic units laterally become finer and grade into sandstone-limestone alternations. These sandstones are dark coloured to black (Fig. 6f) and consist of lithic fragments including carbonates and greenish/reddish metamorphic rocks. Primary sedimentary structures like cross-bedding and grading within beds were occasionally observed. Intercalated limestones are light brown, usually porous and banded, but at some levels, they are buff, massive and well cemented. The limestones are medium- to thick (up to $60 \mathrm{~cm}$ )-bedded.

From north to south, there is a gradual decrease in grain size, and the facies changes from conglomerate to creamywhite marly limestone with organic-rich levels. The thickness of this marly limestone unit is about $45 \mathrm{~m}$ in the north, whilst it reaches $200 \mathrm{~m}$ in the south (Fig. 8). The changes in depositional system from bottom to top (coarsening upwards) are interpreted to reflect infilling of the lacustrine basin by high-energy river systems. Freshwater gastropods in the marl and claystone levels of the Göksögüt Formation include Planorbis sp. and Limnea sp., but were interpreted as endemic and are not suitable for dating (Yağmurlu 1991a). 


\section{Kırkbaş Formation}

Finally, the Kırkbaş Formation consists of reddish, poorly consolidated conglomerate, sandstone, and mudstone alternations. The Kırkbaş Formation unconformably overlies the Göksöğüt Formation and older units and is overlain by Quaternary alluvium. It is well exposed to the east of Terziler and around Kırkbas in the Western part of the basin.

The formation is dominated by partly consolidated, poorly sorted and polymict, angular to sub-rounded, pebbleto boulder-size clasts $(<30 \mathrm{~cm})$ and matrix-supported reddish conglomerates. Clasts are composed of mostly milky-white and grey limestones from the basement, but also include creamy-white to grey lacustrine limestones known from the Neogene units of the basin. Another common facies within this unit comprise alternations of sandstone, siltstone and mudstone with floating pebbles. Stratification is not well developed. However, well-developed carbonate concretions in the red mudstones at some levels indicate development of thick soil profiles, which is probably the main reason for the obliteration of bedding. We interpret the matrix-supported, unsorted and pebble to boulder reddish conglomerates with angular clasts as deposits of an alluvial fan.

Around Tokmacık, Yağmurlu (1991a) reported fossil vertebrates including Hipparion sp. and Mastedon sp. could indicate a Pliocene age for the Kırkbaş Formation.

\section{Structural geology}

Large-scale normal faults delineate the major basement highs surrounding the Yalvaç Basin. Within the basin, numerous mesoscopic faults with a few centimetres to few metre displacements are associated with regionally gentle strata undulations. Most of these structures, lithological variations and geomorphologic characteristics, as well as a first-order analysis of fault geometries and patterns, were mapped based on remote sensing techniques and subsequently verified in the field. Finally, we inferred paleostress configurations during basin evolution using kinematic data from the mesoscopic and syn-depositional faults.

\section{Lineament analysis}

Delineation of the lineaments using remotely sensed data is a complex process and includes some uncertainties related to spatial resolution and spectral characteristics of the used images. To reduce uncertainties, various enhancement techniques including contrast enhancement, colour composite, principal component analysis (PCA) and decorrelation stretching (DS) may help to improve the visual interpretability of an image (Lillesand and Keifer 1999). For this purpose, Landsat ETM+, Advanced Spaceborne Thermal Emission and Reflection Radiometer (ASTER), aerial
Fig. 9 Structural map of the Yalvaç Basin showing main faults and lineaments. Lengthweighted rose diagram prepared from orientations of both discriminated faults and lineaments. Background image is Landsat ETM, and its visualization is enhanced with principal component analysis (PC123 in $R G B$ ) and shaded relief of the DEM with a $25 \times 25$ grid spacing

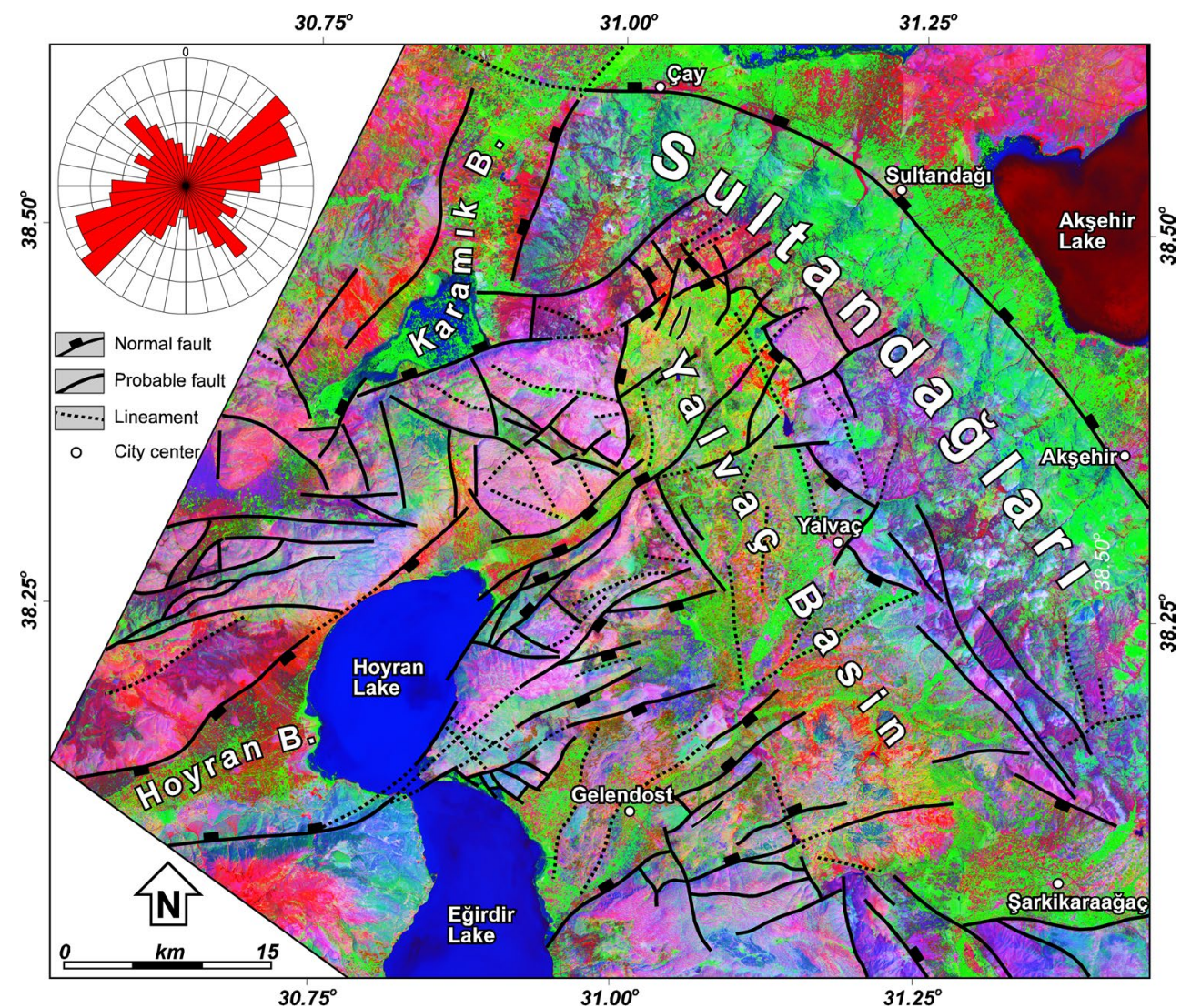



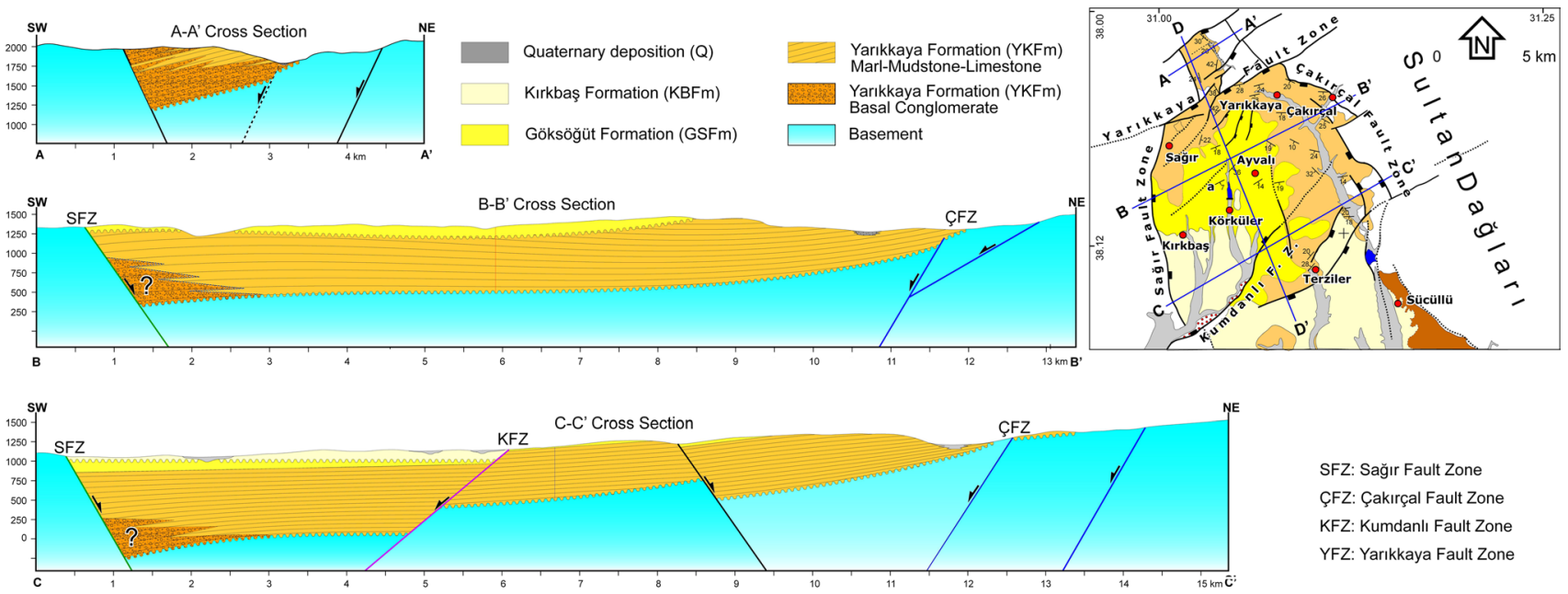

SFZ: Sağır Fault Zone ÇFZ: Çakırçal Fault Zone KFZ: Kumdanlı Fault Zone YFZ: Yarıkkaya Fault Zone

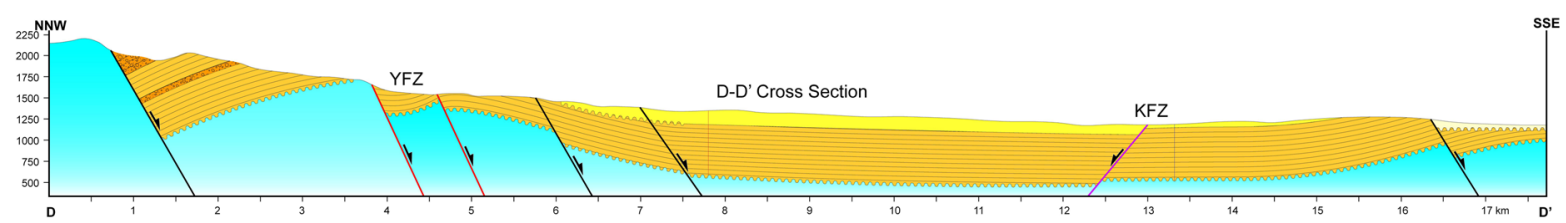

Fig. 10 Structural cross sections across the study area with locations of the sections shown in inset map. Faults in the cross sections with same colour refer to the same fault sets

photographs and Quickbird images obtained from Google Earth were used to improve delineation and characterizing geological lineaments in the study area. All these data types have different spatial and spectral resolutions that can be effective for the determination of structures at various scales. To aid lineament extraction studies, additional $25 \times 25$ resolution digital elevation models (DEM's) prepared from 1/25.000 scale topographic maps were used to improve $3 \mathrm{D}$ visualization.

The lineament extraction process was performed manually on the images. The resultant lineament map of the Yalvaç region is shown in Fig. 9, together with a lengthweighted rose diagram of the extracted lineaments. The map includes both discriminated faults confirmed by field observations and literature data as well as lineaments extracted during this study. The rose diagram (Fig. 9) includes both confirmed faults and lineaments and shows two dominant directions, i.e. NE-SW $\left(\mathrm{N} 45^{\circ}-55^{\circ} \mathrm{E}\right)$ and $\mathrm{NW}-\mathrm{SE}\left(\mathrm{N} 35^{\circ}-45^{\circ} \mathrm{W}\right)$, indicating that the tectonics of the area is controlled by two sub-orthogonal zones of weaknesses (Figs. 9, 10).

\section{Field observations}

Faults encountered in the field are ENE-WSW and NNWSSE striking faults (Fig. 10), all of which show normal motion with subordinate sinistral and dextral oblique components. Among these, the Yarkkaya Fault Zone is
Fig. 11 a Field view of the Yarkkaya Fault Zone (view to NE). Vertical red arrows indicate trace of the fault. b Close-up view of the Yarıkaya fault surface, white arrow indicates hanging-wall motion. c Fault-slip data from the Yarıkkaya Fault Zone. d Hanging valleys along the YFZ (dashed lines) shown on DEM $(25 \times 25$ grid spacing). Red and blue traces with arrows indicate streams and their flow directions, red lines refer to analysed profiles. e Surface profiles across the YFZ. Note sharp changes in topography (knick points) on the YFZ

morphologically the most prominent fault zone, and it consists of three segments. It borders an ENE-WSW trending, linear mountain front rising steeply north of Yarıkkaya (Fig. 11a, b). The main fault plane dips south and ranges between $60^{\circ}$ and $90^{\circ}$ depending on the curvature of the fault plane (Fig. 11c) where it juxtaposes the Miocene Yarıkkaya Formation with basement units (Fig. 11a). Fault segments of the Yarkkkaya Fault Zone are connected through relay ramps (Larsen 1988; Peacock and Sanderson 1991, 1994), e.g. north of Yarkkkaya where a south facing stepping relay ramp is prominent, developed within the basement rocks (Fig. 12a). The overlap zone between the bounding segments is $\sim 1 \mathrm{~km}$ in length (overlap) and $600 \mathrm{~m}$ in width (separation) (Fig. 12b).

Morphologically, the Yarıkkaya Fault Zone can be traced westwards on aerial photographs and satellite images, towards the Karacaören Fault that controls the southern margin of the Quaternary Karamık graben. The Karacaören Fault, however, dips northwards. To the east, the Yarıkkaya Fault Zone dies out within the Sultandağları range. 

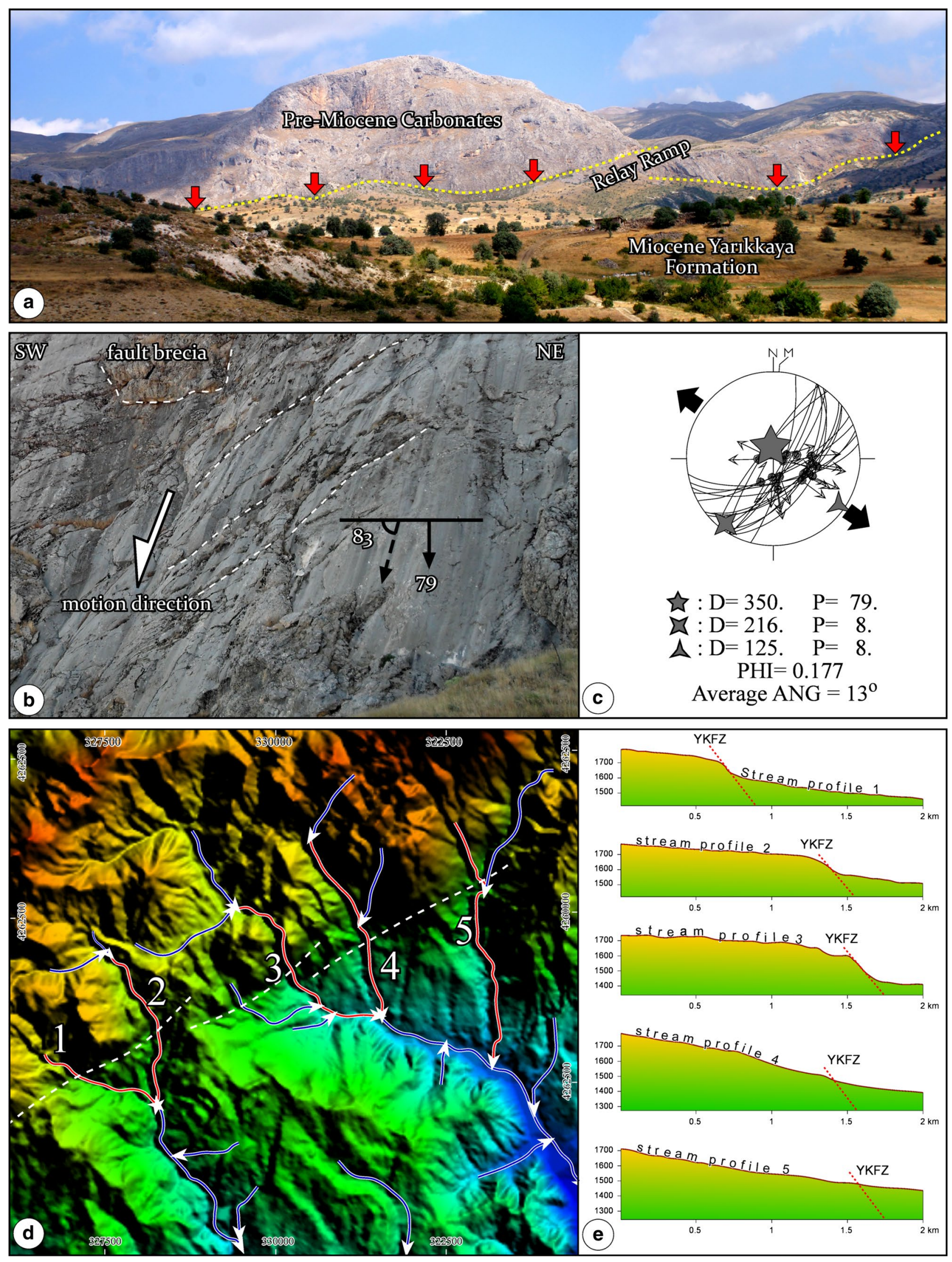


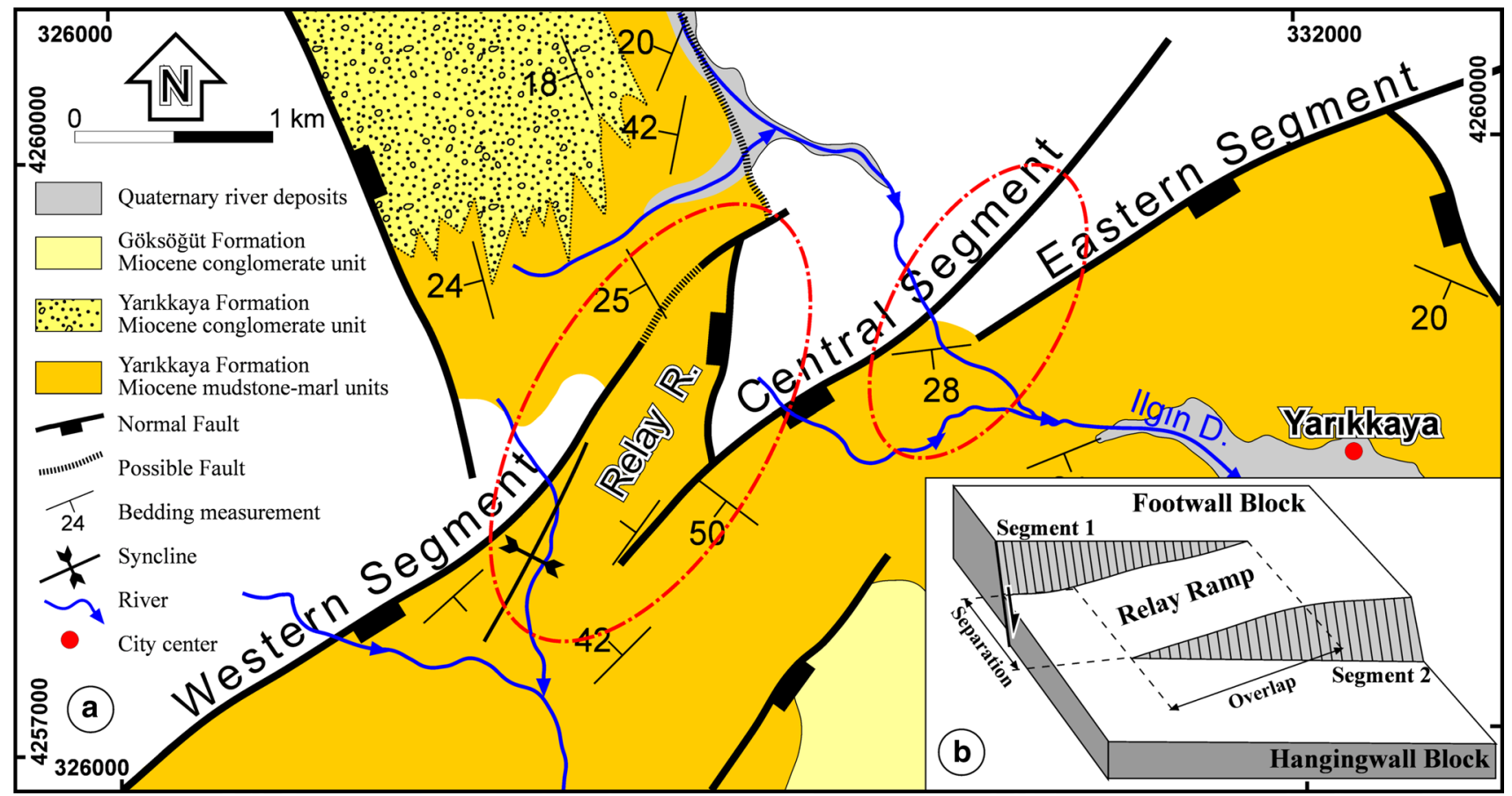

Fig. 12 a Map view of the Yarıkkaya fault segments and intervening relay ramps. b Schematic block diagram of a typical relay ramp between two overstepping segments of a normal fault zone (adopted from Çiftçi and Bozkurt 2007)

Recent activity of the Yarıkaya Fault Zone produced a hanging valley on the footwall side of Yarıkkaya Fault (Fig. 11d). Hanging valleys along the Yarıkkaya Fault Zone were determined from stream profiles that were extracted from the Digital Elevation Model (DEM) using a watershed algorithm. Produced stream profiles are identified in Fig. 11e and are highlighted by red solid lines on the DEM image. Among them, stream profile 3 shows the high elevation difference along the waterway.

The Çakırçal Fault Zone is more than $15 \mathrm{~km}$ long and consists of three segments that each juxtaposes the basin fill against pre-Neogene carbonates and low-grade metamorphic unit of the Sultandağları range along a NNW-SSE zone (Fig. 4). The main fault surfaces are observed to the north of Çakırçal and display a westerly dipping normal fault (Fig. 13a, b). The dip of the fault surface ranges from $20^{\circ}$ to $60^{\circ}$ in the northern segment of the fault and from $60^{\circ}$ to $85^{\circ}$ in the south. Fault segments are linked by E-W trending transverse faults. The northern continuation of the Çakırçal Fault Zone is cut and displaced by the eastern segment of the Yarkkaya Fault Zone. The southern continuation of the fault is difficult to follow on the topography. The Çakırçal Fault Zone is readily recognized in the field by sudden changes in vegetation (Fig. 13a) along the fault trace and juxtaposition of different lithologies. Slickensided surfaces allowed collection of fault-slip data from several locations (Fig. 13c). Kinematic indicators in the fault zone indicate dip-slip normal motion (Fig. 13c), consistent with $\sim \mathrm{E}-\mathrm{W}$ extension.
The Să̆ır Fault Zone is more than $18 \mathrm{~km}$ long and is recognized as a NNE-SSW-oriented, linear valley to the west of Sağır (Fig. 4). It continues to the south along a NNE-SSW-oriented linear mountain front rising gently to the west of Kurkbaş. The main fault is an east-dipping normal fault with a dip ranging from $50^{\circ}$ to $75^{\circ}$ varying with strike curvature of the fault plane (Fig. 13d). It delimits the Western margin of the Yalvaç Basin and separates basin fill from basement carbonate units. Morphologically, the southern continuation of the Sağır Fault Zone can be traced on aerial photographs and satellite images up to the vicinity of Eyüpler (Fig. 4). It is cut by Yarıkkaya Fault Zone in the north and is also cut by NE-SW striking Kumdanlı Fault Zone in the south.

The sudden break in slope and the juxtaposition of different lithologies are used as criteria for the recognition of the Sağır Fault Zone. At some localities, slickensided surfaces allowed collection of fault-slip data that suggest a transtensional character and approximately NW-SE extension (Fig. 13e).

The Kumdanl Fault Zone is a $20 \mathrm{~km}$ long NE-SW trending normal fault zone, which is defined as an active fault in the General Directorate of Mineral Research and Exploration of Turkey database (Active Fault Map of Turkey, 1992). It extends from Misırlı to south of Aşağıtırtar and then disappears into the Hoyran Lake (Figs. 4, 9). It shows a northwest-facing, step-like morphology, and the dip of the fault planes ranges between $70^{\circ}$ and $88^{\circ}$ depending 

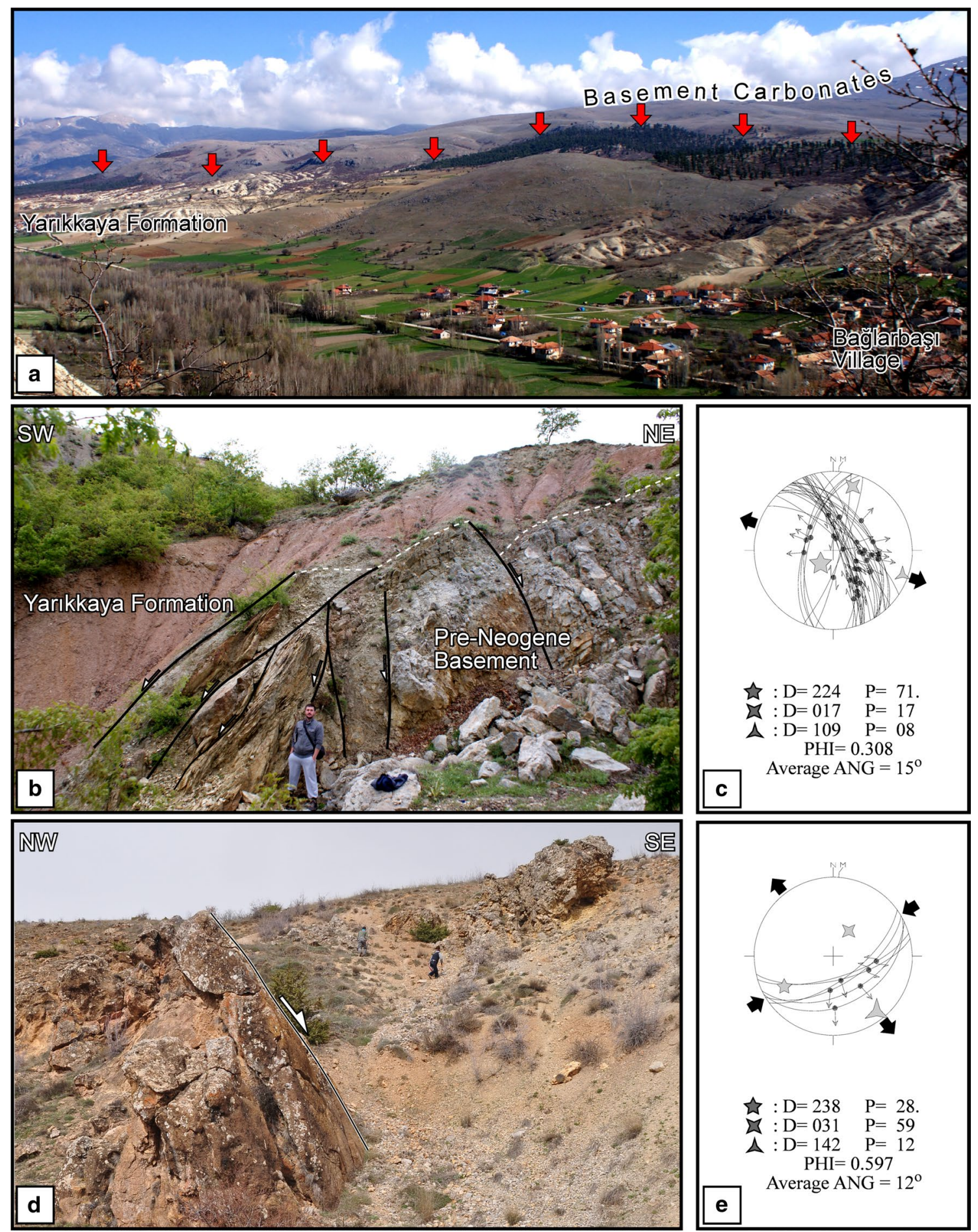

Fig. 13 a Field view of the central segment of the Çakırçal Fault Zone (view to NE). Vertical red arrows indicate the trace of the fault. b Çakırçal Fault Zone between Yarıkkaya Formation and pre-Neogene basement. Note change in thickness of the Yarıkkaya Formation. c Reconstructed paleostress orientations (equal area, lower hemi-

on the along strike curvature of the fault trace. To the west, it separates Plio-Quaternary infill of the Hoyran Basin from pre-Neogene basement in the west (Fig. 14a). Within the sphere projection) collected from site 40 (location in Fig. 18). d Fault scarp of the Sağır Fault Zone (SFZ) northwest of Sağır. e Paleostress configuration based on kinematic indicators collected from the SFZ (equal area, lower hemisphere projection). White arrow denotes dip of the fault surface and movement direction of the hanging-wall block

Yalvaç Basin, it cuts and displaces basin units. Morphologically, the north-eastern continuation of the Kumdanlı Fault Zone dies out within the infill of the Yalvaç Basin (Fig. 14a). 

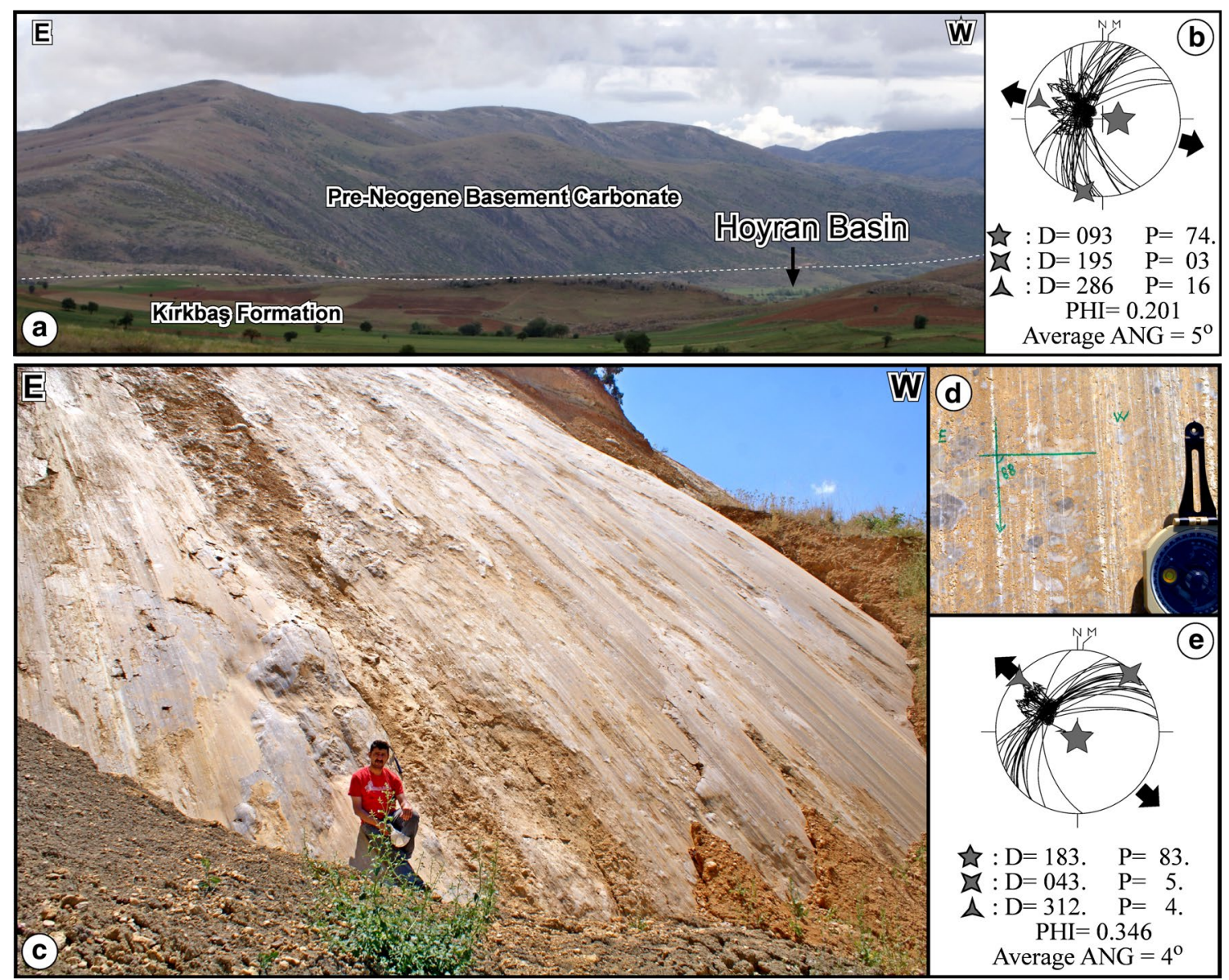

Fig. 14 a Morphological expression of the Kumdanlı Fault Zone (KFZ) delimiting the south-eastern boundary of the Plio-Quaternary Hoyran Basin. b Configuration of paleostress orientations based on fault-slip data collected from the KFZ around Aşağıtırtar, site 25, see

The Kumdanlı Fault Zone is recognized as a NE-SWoriented linear mountain front rising steeply in the north of Aşağıtırtar. It creates a conspicuous fault scarp with welldeveloped slickensides and is associated with an active colluvial wedge. Our fault-slip data show that the Kumdanl1 Fault Zone is an oblique normal fault accommodating $\sim$ E-W extensional strain (Fig. 14b).

The Yaka Fault Zone (Figs. 4, 14c-e) is an about $6 \mathrm{~km}$ wide and more than $20 \mathrm{~km}$ long, $\sim \mathrm{NE}-\mathrm{SW}$ trending normal fault zone. The south-western tip of the fault is located to the south of Gelendost, and the fault zone continues northeastwards to Madenli. The dips of the fault surfaces range between $45^{\circ}$ and $70^{\circ}$. The Yaka Fault Zone controls the southern margin of the Yalvaç Basin and separates the Miocene Yarıkkaya Formation from carbonate basement units. In places, the Yaka Fault Zone is cut by NW-SE trending faults.

A sudden break in topography, well-preserved fault scarps (Fig. 14c, d) and juxtaposition of basement rock and basin fill are common morphotectonic features that allow
Fig. 18 (equal area, lower hemisphere projection). c Field view of the eastern tip of the Yaka Fault Zone (YAFZ). d Well-developed slickenlines on the fault surface and $\mathbf{e}$ stereoplot of these slip data (equal area, lower hemisphere)

recognition of the Yaka Fault Zone. Well-preserved slickensides and fault-slip data show normal motion indicating $\sim$ NE-SW extensional deformation (Fig. 14e).

\section{Paleostress analysis}

Methods and data

We carried out detailed kinematic analysis on mesoscopic structures to unravel the paleostress evolution of the Yalvaç Basin and use Angelier's direct inversion routine (INVD) (Angelier 1994) on fault-slip data.

Paleostress inversion provides an analysis of fault orientation and kinematic indicators to infer principle paleostresses (Carey and Burinier 1974; Etchecopar et al. 1981; Angelier 1990, 1994). The result of the analysis contains information of the stress conditions that were responsible for brittle deformation events. All methods for reconstruction of 
the stress orientation rely on the following assumptions: (1) the bulk state of stress in a small area is uniform, (2) the slip direction is parallel to the maximum resolved shear stress on each fault plane (Wallace-Bott assumption), (3) all movements occur under a same stress tensor and (4) the strain is non-rotational. To determine orientations of the three principal stress axes $\left(\sigma_{1}\right.$ : maximum, $\sigma_{2}$ : intermediate and $\sigma_{3}$ : minimum) and the shape ratio of stress ellipsoid $\left(\Phi=\left(\sigma_{2}-\sigma_{3}\right) /\right.$ $\left(\sigma_{1}-\sigma_{3}\right)$ ranging between two extreme values of 0 and 1 , the best fitting-reduced stress tensor based on the given fault-slip data is computed (Angelier 1994). According to Angelier (1994), the $\Phi$ ratio constrains all-possible cases between uniaxial $\left(\sigma_{2}=\sigma_{3} ; \Phi=0\right.$ or $\left.\sigma_{1}=\sigma_{2} ; \Phi=1\right)$ and tri-axial stress configurations $\left(\sigma_{1}>\sigma_{2}>\sigma_{3} ; \Phi=0.5\right)$.

Another data set used to construct and to analyse paleostress configurations concerns veins. Dunne and Hancock (1994) argued that mineral growth directions are perpendicular to fracture walls and are parallel to $\sigma_{3}$; therefore, it provides minor principal paleostress orientations. A best fit great circle passing through the poles of the vein planes contains $\sigma_{1}$ and $\sigma_{3}$, and the pole of the plane corresponds to the intermediate principle stress $\left(\sigma_{2}\right)$. The mean lineation vector represents the mean vector of the vein poles and corresponds to the minimum effective principal stress $\left(\sigma_{3}\right)$. The intersection of the mean great circles for the veins and the great circle containing the poles (auxiliary plane) corresponds to the major principal stress $\left(\sigma_{1}\right)$. Intermediate and major principal stresses are approximately parallel to the vein orientation, and therefore, vein data are insensitive to the orientation of these stresses.

\section{Fault-slip analysis}

We collected 1,304 fault-slip measurements from 78 sites of mesoscopic faults cutting the Yalvaç Basin fill and the major fault zones described previously (see Supplementary Information and Table 1), including orientations of the fault planes, slip directions and senses of relative movement. A rose diagram of the strikes of these fault planes indicates a dominant NE-SW strike orientation. Dips of the faults range from $15^{\circ}$ to $90^{\circ}$, with the majority between $50^{\circ}$ and $75^{\circ}$ (Supplementary Information).

Stress inversion was done for each site separately, using 1181 fault-slip measurements and applying the direct inversion method (INVD) (Angelier 1994). From 78 sites, 92 stress configurations were constructed (Table 1). Angelier (1994) considered a maximum angular deviation (ANG) of $<22.5^{\circ}$ a good match, and an ANG between $22.5^{\circ}$ and $45^{\circ}$ a poor match. A value $>45^{\circ}$ shows very poor consistency between the measured slip data and the computed stress tensor. Following this, we applied a cut-off angle of $45^{\circ}$, which eliminated a total of 122 fault-slip measurements from the dataset, corresponding to $9.3 \%$ of the data.
Using the misfit criteria and separation procedure, sites $16,31,33,42,46,51,64$ and 65 produced two different paleostress configurations. The separated configurations are labelled as ' $\mathrm{B}$ ' in Table 1. In some basement sites, overprinting slickensides were documented. For those, each slip direction was analysed separately and considered evidence for at least two deformation phases. The absence of stratigraphic constraints precludes dating of these phases in the basement that information is retrieved from the growth faults in the various formations. This type of faults develops within the sediment pile during sedimentation. It is easy to discriminate them from the post-sedimentary faults by dip-parallel fault displacement variations (Fig. 15).

Syn-sedimentary structures (Fig. 15) are crucial for paleostress stratigraphy, since these dates the age of the constructed paleostress configuration. In site 78, at the base of the Middle Miocene Yarıkkaya Formation, syn-sedimentary faults with dextral strike-slip movement (Fig. 15b) were found. This is the only site with syn-sedimentary faults with strike-slip slickensides and is interpreted to be a transfer zone within the Yarıkkaya Fault Zone (Fig. 15c). Site 69 also at the base of the Yarıkkaya Formation preserved syn-sedimentary normal faults (Fig. 15d, f, g) with well-preserved fault-slip indicators and fault planes striking $\mathrm{N}-\mathrm{S}$ to NE-SW (Fig. 15f). The inferred extension direction from this location is NW-SE (Fig. 15h). Finally, sites 5, 60, $65,68,69$ and 78 contain syn-sedimentary normal faults that yield a vertical $\sigma_{1}$ orientation and an almost radial $\sigma_{3}$ orientation (Fig. 15e). There, the horizontal components of intermediate and minor stress do not have a preferred orientation, indicating paleostress permutations (Homberg et al. 1997), which is common in uniaxial stress conditions where magnitudes of two principal stresses are equal or close to equal (Kaymakci 2006 ).

\section{Veins}

Veins are present within the sandstone unit of the Göksöğüt Formation. The vein fill and the host rock have a distinctly different colour and texture. Two veins sets exist: (1) a dominant E-W striking set and (2) a subordinate N-S striking set. Most of the E-W striking veins are up to $25 \mathrm{~cm}$ thick (Fig. 16a) and dominantly around $10 \mathrm{~cm}$. N-S striking veins are very thin with a maximum thickness of around 1-2 cm (Fig. 16b). The cross-cutting relationship in Fig. $15 \mathrm{~b}$ between these vein sets suggests that $\mathrm{N}-\mathrm{S}$ striking veins generally post-date the $\mathrm{E}-\mathrm{W}$ striking ones.

The growth pattern of the veins varies, with some that developed symmetrically, but most showing asymmetric growth, such that the thicknesses of the vein fills grown from either side of the vein wall are not equal. In most veins, calcite overgrowth patterns and banded structure of the calcite fill are well developed (Fig. 16a). Wherever 
Table 1 Coordinates of the paleostress measurement sites and statistical parameters of the constructed paleostress orientations for the Yalvaç Basin

\begin{tabular}{|c|c|c|c|c|c|c|c|c|c|}
\hline Loc. & Long. & Lat. & $\sigma_{1}\left(P^{\circ} / D^{\circ}\right)$ & $\sigma_{2}\left(P^{\circ} / D^{\circ}\right)$ & $\sigma_{3}\left(P^{\circ} / D^{\circ}\right)$ & $\Phi$ & $\begin{array}{l}\text { Mean } \\
\text { ANG }\end{array}$ & Mean RUP & $N$ \\
\hline Y1 & 31.13771 & 38.38782 & $170 / 75$ & $287 / 07$ & $019 / 14$ & 0.362 & 14 & 42 & 11 \\
\hline $\mathrm{Y} 2$ & 31.05173 & 38.46330 & $018 / 78$ & $236 / 09$ & $145 / 07$ & 0.477 & 11 & 38 & 10 \\
\hline Y3 & 31.03761 & 38.45680 & $065 / 68$ & $181 / 10$ & $275 / 20$ & 0.234 & 15 & 37 & 10 \\
\hline Y4 & 31.03901 & 38.47502 & $041 / 83$ & $222 / 07$ & $132 / 00$ & 0.602 & 14 & 40 & 16 \\
\hline Y5 & 31.03195 & 38.48403 & $050 / 82$ & $307 / 02$ & $216 / 08$ & 0.771 & 11 & 27 & 10 \\
\hline Y6 & 31.03806 & 38.47789 & $113 / 80$ & $217 / 03$ & $307 / 10$ & 0.554 & 10 & 31 & 12 \\
\hline Y7 & 31.03245 & 38.45948 & $330 / 72$ & $212 / 08$ & $120 / 15$ & 0.162 & 12 & 27 & 15 \\
\hline Y8 & 31.10152 & 38.36944 & $014 / 77$ & $231 / 10$ & $140 / 08$ & 0.464 & 10 & 25 & 7 \\
\hline Y9 & 31.10028 & 38.15304 & $167 / 81$ & $067 / 02$ & $336 / 09$ & 0.432 & 9 & 21 & 6 \\
\hline Y10 & 31.09762 & 38.14761 & $137 / 74$ & $239 / 03$ & $330 / 16$ & 0.230 & 8 & 25 & 14 \\
\hline Y11 & 31.04696 & 38.11092 & $139 / 76$ & 023/06 & $292 / 12$ & 0.354 & 9 & 22 & 12 \\
\hline Y12 & 30.98069 & 38.44016 & $062 / 53$ & $261 / 36$ & $164 / 09$ & 0.025 & 29 & 64 & 4 \\
\hline Y13 & 30.99456 & 38.43732 & $260 / 73$ & $009 / 06$ & $101 / 16$ & 0.540 & 23 & 50 & 9 \\
\hline Y14 & 31.04422 & 38.42888 & $319 / 74$ & $107 / 14$ & $199 / 08$ & 0.424 & 6 & 16 & 14 \\
\hline Y15 & 30.98357 & 38.58922 & $246 / 70$ & $059 / 20$ & $150 / 02$ & 0.346 & 17 & 35 & 12 \\
\hline Y16 & 30.95261 & 38.57671 & $160 / 68$ & $346 / 22$ & $255 / 02$ & 0.329 & 11 & 32 & 6 \\
\hline Y16B & 30.95261 & 38.57671 & $070 / 53$ & $164 / 03$ & $256 / 37$ & 0.766 & 18 & 63 & 4 \\
\hline Y17 & 30.91048 & 38.44091 & $198 / 86$ & $005 / 04$ & 095/01 & 0.185 & 15 & 39 & 20 \\
\hline Y18 & 30.88609 & 38.42271 & $212 / 71$ & $014 / 18$ & $106 / 05$ & 0.470 & 7 & 17 & 16 \\
\hline Y19 & 30.87961 & 38.42013 & $271 / 80$ & 057/09 & $148 / 06$ & 0.166 & 21 & 43 & 17 \\
\hline Y20 & 30.87036 & 38.41647 & $105 / 81$ & $233 / 06$ & $324 / 07$ & 0.345 & 8 & 17 & 19 \\
\hline Y21 & 30.79975 & 38.38981 & $199 / 68$ & $315 / 10$ & $048 / 20$ & 0.202 & 9 & 20 & 12 \\
\hline Y22 & 30.80767 & 38.39748 & $166 / 62$ & $032 / 20$ & $295 / 19$ & 0.428 & 12 & 44 & 7 \\
\hline Y23 & 30.81740 & 38.39989 & $339 / 76$ & $117 / 11$ & $209 / 09$ & 0.406 & 20 & 46 & 26 \\
\hline Y24 & 30.58279 & 38.14960 & $043 / 72$ & $234 / 17$ & $143 / 03$ & 0.184 & 8 & 23 & 10 \\
\hline Y24B & 30.58279 & 38.14960 & $267 / 80$ & $003 / 01$ & $093 / 10$ & 0.660 & 3 & 17 & 5 \\
\hline Y25 & 30.91619 & 38.26183 & $093 / 74$ & $195 / 03$ & $286 / 16$ & 0.201 & 5 & 16 & 27 \\
\hline Y26 & 30.91792 & 38.26483 & $129 / 71$ & $017 / 07$ & $285 / 17$ & 0.206 & 5 & 17 & 17 \\
\hline Y27 & 30.98231 & 38.303755 & $280 / 76$ & $182 / 02$ & $092 / 14$ & 0.103 & 17 & 32 & 14 \\
\hline Y28 & 30.95462 & 38.29039 & $189 / 75$ & $049 / 11$ & $317 / 09$ & 0.407 & 9 & 24 & 23 \\
\hline Y29 & 30.94765 & 38.26587 & $183 / 72$ & $015 / 18$ & $284 / 04$ & 0.540 & 16 & 32 & 17 \\
\hline Y29B & 30.94765 & 38.26587 & $017 / 77$ & $124 / 04$ & $215 / 13$ & 0.388 & 18 & 38 & 9 \\
\hline Y30 & 30.93503 & 38.13651 & $321 / 77$ & $055 / 01$ & $145 / 13$ & 0.264 & 13 & 27 & 20 \\
\hline Y31 & 30.86395 & 38.14495 & $279 / 73$ & $057 / 13$ & $149 / 11$ & 0.327 & 3 & 15 & 6 \\
\hline Y31B & 30.86395 & 38.14495 & $047 / 63$ & $171 / 16$ & $267 / 22$ & 0.895 & 9 & 31 & 6 \\
\hline Y32 & 31.11251 & 38.11220 & $142 / 73$ & $258 / 08$ & $350 / 15$ & 0.395 & 10 & 27 & 23 \\
\hline Y33 & 30.96482 & 38.05288 & $096 / 77$ & $264 / 13$ & $355 / 03$ & 0.097 & 21 & 39 & 24 \\
\hline Y33B & 30.96482 & 38.05288 & $073 / 43$ & $171 / 08$ & $269 / 46$ & 0.456 & 9 & 20 & 5 \\
\hline Y34 & 30.96522 & 38.05007 & $183 / 83$ & $043 / 05$ & $312 / 04$ & 0.346 & 4 & 10 & 22 \\
\hline Y35 & 30.98866 & 38.02596 & $267 / 80$ & 040/07 & $131 / 08$ & 0.433 & 13 & 37 & 11 \\
\hline Y36 & 31.09925 & 38.15094 & $312 / 64$ & $153 / 25$ & 059/08 & 0.231 & 16 & 50 & 17 \\
\hline Y37 & 31.00132 & 38.43218 & $238 / 28$ & $031 / 59$ & $142 / 12$ & 0.597 & 12 & 31 & 6 \\
\hline Y37B & 31.00132 & 38.43218 & $013 / 24$ & $221 / 64$ & $108 / 11$ & 0.816 & 9 & 27 & 8 \\
\hline Y38 & 31.03165 & 38.48628 & $306 / 67$ & $112 / 22$ & $204 / 05$ & 0.563 & 15 & 31 & 17 \\
\hline Y39 & 31.05372 & 38.46439 & $146 / 69$ & $264 / 10$ & $358 / 18$ & 0.159 & 10 & 30 & 12 \\
\hline Y40 & 31.16047 & 38.35874 & $224 / 71$ & $017 / 17$ & $109 / 08$ & 0.308 & 15 & 38 & 31 \\
\hline Y41 & 31.16080 & 38.36128 & $204 / 54$ & $016 / 36$ & $109 / 04$ & 0.640 & 8 & 24 & 21 \\
\hline Y42 & 31.14420 & 38.38292 & $008 / 62$ & $203 / 28$ & $110 / 06$ & 0.570 & 11 & 31 & 17 \\
\hline Y42B & 31.14420 & 38.38292 & $249 / 63$ & $067 / 27$ & $157 / 01$ & 0.373 & 7 & 28 & 7 \\
\hline
\end{tabular}


Table 1 continued

$\sigma_{1}, \sigma_{2}$ and $\sigma_{3}$ major, intermediate, and minor principle stresses, D/P: direction/plunge, $\Phi$ : stress ratio, ANG: maximum allowed angular divergence, RUP: maximum allowed quality estimator, $\mathrm{N}$ : number of measurement for each site

\begin{tabular}{|c|c|c|c|c|c|c|c|c|c|}
\hline Loc. & Long. & Lat. & $\sigma_{1}\left(P^{\circ} / D^{\circ}\right)$ & $\sigma_{2}\left(P^{\circ} / D^{\circ}\right)$ & $\sigma_{3}\left(P^{\circ} / D^{\circ}\right)$ & $\Phi$ & $\begin{array}{l}\text { Mean } \\
\text { ANG }\end{array}$ & Mean RUP & $N$ \\
\hline Y43 & 31.22980 & 38.25979 & $194 / 75$ & $293 / 02$ & $023 / 15$ & 0.168 & 15 & 43 & 18 \\
\hline Y44 & 31.29319 & 38.22349 & $282 / 86$ & $109 / 04$ & $019 / 00$ & 0.370 & 25 & 51 & 16 \\
\hline Y45 & 31.28874 & 38.22342 & $041 / 77$ & $228 / 13$ & $138 / 02$ & 0.311 & 17 & 37 & 7 \\
\hline Y46 & 31.32863 & 38.15713 & $030 / 73$ & $236 / 15$ & $144 / 07$ & 0.393 & 7 & 23 & 17 \\
\hline Y46B & 31.32863 & 38.15713 & $161 / 17$ & $035 / 63$ & $258 / 20$ & 0.503 & 3 & 24 & 10 \\
\hline Y47 & 31.12237 & 38.39617 & $347 / 65$ & $134 / 21$ & $229 / 12$ & 0.136 & 7 & 22 & 7 \\
\hline Y48 & 31.05158 & 38.45823 & $284 / 73$ & $028 / 04$ & $119 / 16$ & 0.339 & 6 & 22 & 11 \\
\hline Y49 & 31.14262 & 38.36721 & $298 / 72$ & $115 / 18$ & $205 / 01$ & 0.786 & 17 & 51 & 11 \\
\hline Y50 & 31.11767 & 38.45198 & $029 / 70$ & $273 / 09$ & $180 / 18$ & 0.361 & 11 & 33 & 7 \\
\hline Y51 & 31.08758 & 38.46440 & $051 / 69$ & $304 / 07$ & $211 / 20$ & 0.435 & 16 & 37 & 11 \\
\hline Y51B & 31.08758 & 38.46440 & $107 / 26$ & $238 / 53$ & $004 / 24$ & 0.815 & 3 & 19 & 5 \\
\hline Y52 & 31.08700 & 38.46478 & $278 / 71$ & 019/04 & $111 / 19$ & 0.308 & 20 & 39 & 8 \\
\hline Y53 & 31.08590 & 38.46465 & $097 / 55$ & $287 / 34$ & $194 / 05$ & 0.465 & 5 & 21 & 8 \\
\hline Y54 & 31.04024 & 38.46373 & $075 / 78$ & $223 / 11$ & $314 / 07$ & 0.338 & 13 & 28 & 21 \\
\hline Y54B & 31.04024 & 38.46373 & $026 / 73$ & $231 / 15$ & $139 / 07$ & 0.342 & 8 & 23 & 21 \\
\hline Y55 & 31.04049 & 38.46835 & $038 / 74$ & $252 / 13$ & $160 / 09$ & 0.470 & 7 & 18 & 22 \\
\hline Y56 & 31.04261 & 38.46814 & $122 / 81$ & $236 / 04$ & $327 / 08$ & 0.429 & 13 & 32 & 22 \\
\hline Y57 & 31.04261 & 38.46814 & $085 / 70$ & $248 / 19$ & $340 / 06$ & 0.480 & 8 & 23 & 16 \\
\hline Y58 & 31.04259 & 38.46911 & $233 / 70$ & $022 / 17$ & $115 / 10$ & 0.532 & 9 & 39 & 9 \\
\hline Y59 & 31.24080 & 38.27233 & $090 / 67$ & $299 / 20$ & $205 / 10$ & 0.132 & 16 & 43 & 26 \\
\hline Y60 & 31.21275 & 38.16514 & $166 / 64$ & $000 / 26$ & $267 / 06$ & 0.178 & 14 & 32 & 4 \\
\hline Y61 & 31.03743 & 38.48212 & $125 / 66$ & $246 / 13$ & $341 / 20$ & 0.174 & 5 & 22 & 6 \\
\hline Y62 & 31.03293 & 38.48301 & $237 / 75$ & $051 / 15$ & $142 / 02$ & 0.358 & 1 & 13 & 4 \\
\hline Y63 & 31.22607 & 38.25913 & $206 / 83$ & 048/07 & $318 / 03$ & 0.466 & 6 & 21 & 23 \\
\hline Y64 & 31.14301 & 38.36819 & $351 / 19$ & $135 / 66$ & $257 / 13$ & 0.776 & 6 & 15 & 15 \\
\hline Y64B & 31.14301 & 38.36819 & $061 / 79$ & $287 / 08$ & $196 / 08$ & 0.592 & 8 & 28 & 8 \\
\hline Y65 & 31.11001 & 38.45832 & $255 / 47$ & $350 / 05$ & $085 / 43$ & 0.306 & 15 & 35 & 8 \\
\hline Y65B & 31.11001 & 38.45832 & $250 / 69$ & $044 / 19$ & $137 / 09$ & 0.367 & 3 & 22 & 4 \\
\hline Y66 & 31.11613 & 38.45385 & $316 / 44$ & $089 / 35$ & $198 / 25$ & 0.551 & 6 & 31 & 6 \\
\hline Y67 & 31.11763 & 38.45219 & $187 / 76$ & 094/01 & $003 / 14$ & 0.466 & 11 & 25 & 20 \\
\hline Y68 & 31.03185 & 38.48398 & $048 / 02$ & $138 / 24$ & $314 / 66$ & 0.386 & 12 & 38 & 17 \\
\hline Y69 & 31.03806 & 38.47789 & $152 / 74$ & 038/07 & $306 / 15$ & 0.330 & 9 & 28 & 24 \\
\hline Y70 & 31.04023 & 38.46365 & $184 / 89$ & 048/01 & $318 / 01$ & 0.393 & 4 & 11 & 6 \\
\hline Y71 & 31.08752 & 38.46455 & $222 / 64$ & $067 / 24$ & $332 / 10$ & 0.711 & 7 & 28 & 11 \\
\hline Y71B & 31.08752 & 38.46455 & $291 / 52$ & $096 / 37$ & $191 / 08$ & 0.353 & 9 & 25 & \\
\hline Y72 & 31.04509 & 38.43022 & $077 / 37$ & $297 / 45$ & $184 / 21$ & 0.977 & 5 & 16 & 9 \\
\hline Y73 & 31.09907 & 38.15264 & $107 / 38$ & $267 / 50$ & $009 / 10$ & 0.896 & 6 & 14 & 10 \\
\hline Y74 & 31.09888 & 38.15169 & $185 / 70$ & $042 / 16$ & $309 / 11$ & 0.479 & 14 & 39 & 17 \\
\hline Y75 & 31.09896 & 38.15155 & $355 / 63$ & $165 / 27$ & $257 / 04$ & 0.152 & 11 & 29 & 17 \\
\hline Y76 & 31.09926 & 38.15096 & $328 / 69$ & $140 / 21$ & $231 / 03$ & 0.199 & 20 & 47 & 13 \\
\hline Y77 & 31.09750 & 38.14603 & $209 / 66$ & 070/18 & $335 / 14$ & 0.397 & 13 & 37 & 9 \\
\hline Y780 & 31.03101 & 38.48634 & $238 / 42$ & $075 / 47$ & $336 / 09$ & 0.337 & 17 & 49 & 13 \\
\hline Y78TC & 31.03101 & 38.48634 & $234 / 17$ & $104 / 65$ & $330 / 18$ & 0.570 & 17 & 46 & 13 \\
\hline
\end{tabular}

The strikes of the veins range between $057^{\circ} \mathrm{N}$ and $107^{\circ} \mathrm{N}$ (Fig. 16c). A best fit great circle passing through the poles of the vein planes is oriented $347^{\circ} \mathrm{N} / 81 \mathrm{E}$. The mean lineation vector is found as $167 / 04$, which refers to observed, the vein-filling calcites are roughly equant and show crystal faces. Occasionally, veins may contain fragments of the host rock (breccia zones) coated with a calcite layer (Fig. 16b). 
Fig. 15 a Syn-sedimentary faults near the base of the Yarıkkaya Formation (Site 78, for location see Fig. 18). b Configuration of paleostress orientations based on fault-slip data collected from site 78 (Tilt corrected), see Fig. 18 (equal area, lower hemisphere projection). c Detail showing dextral strikeslip slickensides with minor normal component. d Synsedimentary normal faults, also near the base of the Yarıkkaya Formation, e Configuration of paleostress orientations based on fault-slip data collected from site 69, see Fig. 18 (equal area, lower hemisphere projection). f Detail showing slickensides indicating normal (downdip) movement, $\mathbf{g}$ detail of synsedimentary normal fault which causes vertical displacement of the coal levels, $\mathbf{h}$ rose diagram showing directions of all synsedimentary faults in the study area, note that orientation of minor stress is variable
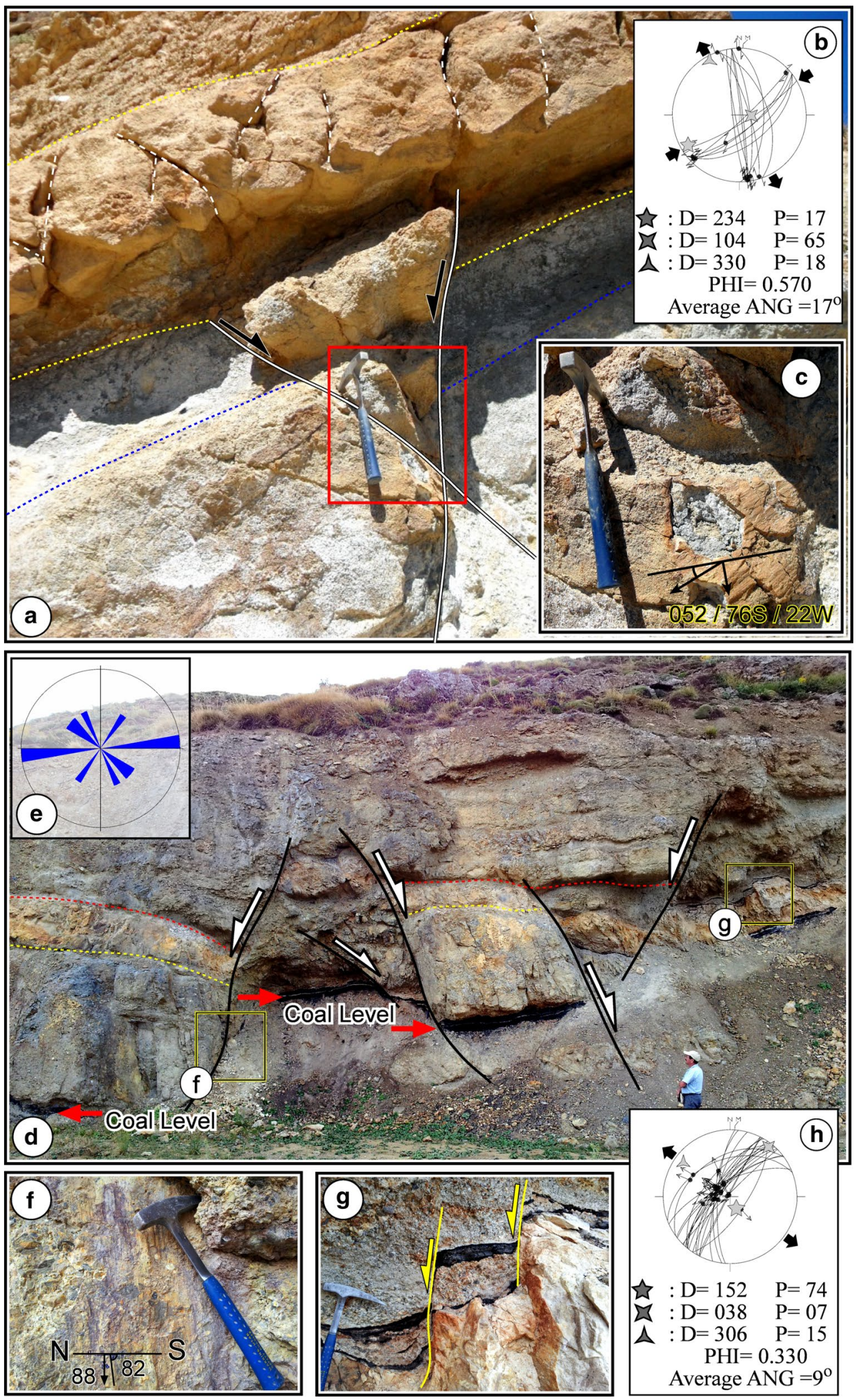

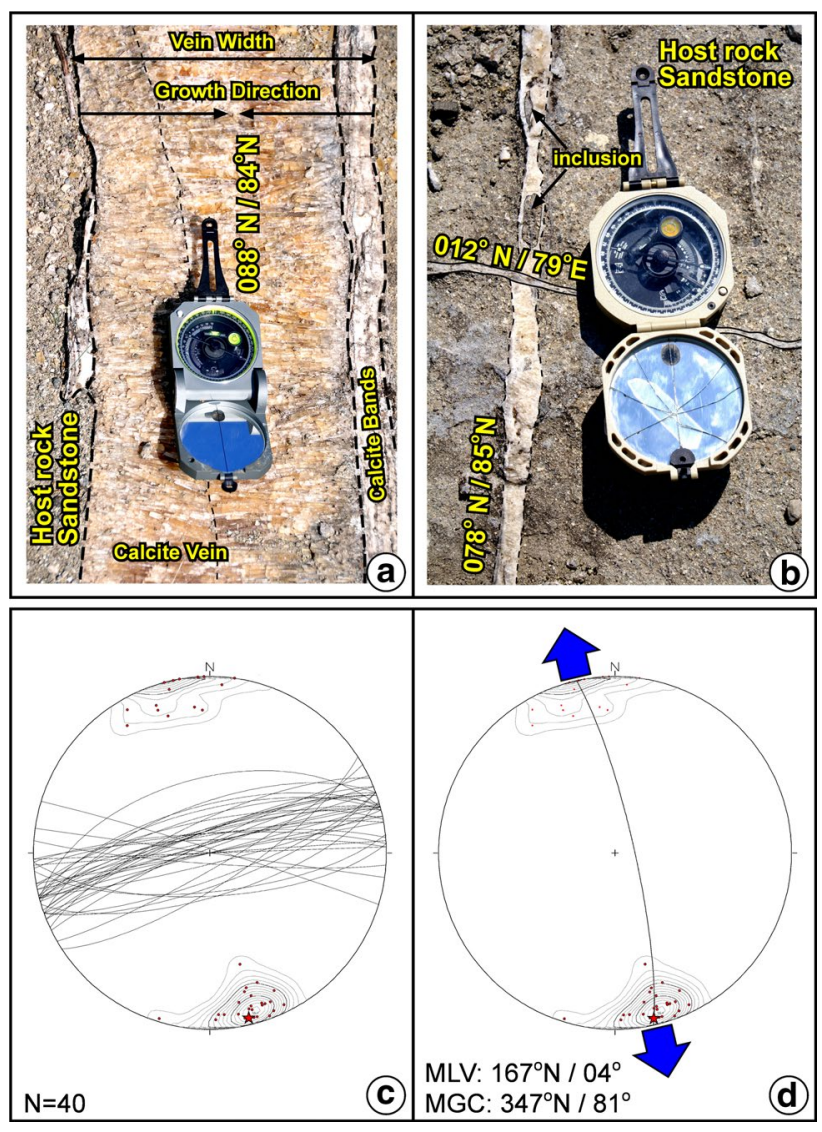

Fig. 16 Vein in the Göksöğüt Formation a approximately E-W striking, syntaxial calcite vein, where crystals grow from the wall rock into the vein. b Cross-cutting relationship between vein sets. Approximately N-S striking young vein cuts across and offsets older, approximately E-W striking vein. c Stereoplots of veins and d contour diagrams of poles to the veins (red dots) with orientations of reconstructed principal stress directions (blue arrows)

the minimum effective principal stress $\left(\sigma_{3}\right)$ (Fig. 16d). The intersection of the mean great circles for the veins and the great circle containing the poles (auxiliary plane) is 045/80, which is close to vertical. Therefore, the tectonic regime during the emplacement of these veins was extensional. The orientation of intermediate paleostress $\left(\sigma_{2}\right)$ vector was $90^{\circ}$ apart from $\sigma_{1}$ along the mean great circle of vein planes: $256 / 09^{\circ}$. The horizontal component of $\sigma_{3}$ is approximately $\mathrm{N}-\mathrm{S}$ (Fig. 16d) and indicates the dominant extension direction.

\section{Spatial characteristics}

Paleostress analyses from the Yalvaç Basin unravel the stress regimes that controlled the geometry and evolution of the basin. To this end, we performed detailed analyses of the constructed paleostress orientations and compared these to the regional structures. Figure 17 shows the density diagram of principal stress orientations ( $\sigma_{1}, \sigma_{2}$ and $\sigma_{3}$, respectively) as well as histograms of the $\phi$ values for the whole data set. Orientations of $\sigma_{1}$ are generally (sub-)vertical (Fig. 17a) as they are concentrated in the centre of the diagram. Stereographic projections of $\sigma_{2}$ and $\sigma_{3}$ orientations show a wide scatter but are consistently sub-horizontal (Fig. 17b and c) consistent with the extensional nature of the Yalvaç Basin. This scattering may be due to $\sigma_{2}-\sigma_{3}$ being near equal, implying uniaxial stress conditions that gives way to multi-directional extension.

The horizontal components of the $\sigma_{3}$ directions are plotted in Fig. 18. Our field study reveals that NE-SW and NW-SE trending major fault sets controlled the structure of the area. Most $\sigma_{3}$ directions, including strikeslip solutions (sites 5, 16B, 31B, 33B, 37B, 46B, 51B, 64, 66, 73 and 78), also indicate two dominant extension directions (Fig. 18c). These directions may be controlled mainly by the geometry of the associated major faults rather than the regional stress pattern: the orientation of $\sigma_{3}$ is almost always perpendicular to the adjacent major fault. The paleostress inversion results based on the growth structures in the various formations, in combination with the sedimentological evidence that the main faults that are bounding the basin today were also forming the basin margin during deposition, indicate that these normal faults were simultaneously active during deposition.

\section{Temporal relationships}

Temporal changes of the paleostress configurations throughout the stratigraphy are critical to constrain paleostress configurations throughout the basin evolution. Basin strata recorded paleostress orientations that were coeval with and after sedimentation (Fig. 16), while the basement likely recorded the entire paleostress evolution (c.f. Kleinspehn et al. 1989). Temporal characteristics of the basin are given in Fig. 19. Relative ages of the paleostress data are ordered based on (1) the age of the rocks from which the fault-slip data were collected and (2) crosscutting relationships between the faults and the stratigraphy. The results reveal that there is neither temporal nor spatial variation in the paleostress configurations since the Middle Miocene, and two dominant E-W to NE-SW and $\mathrm{N}-\mathrm{S}$ to NW-SE extension directions consequently acted in tandem throughout the evolution of the Yalvaç Basin and still do today. From this, we infer that present-day stress configuration has prevailed since the onset of sedimentation in the Yalvaç Basin, i.e. since at least Middle Miocene times. 

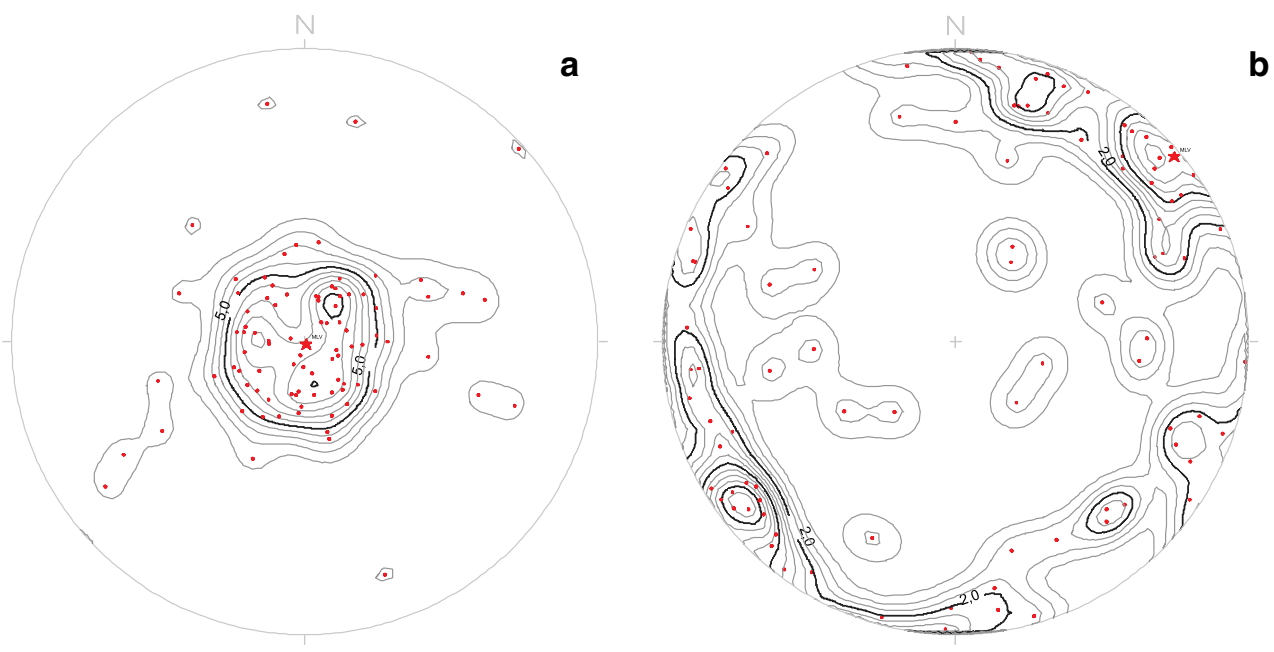

b
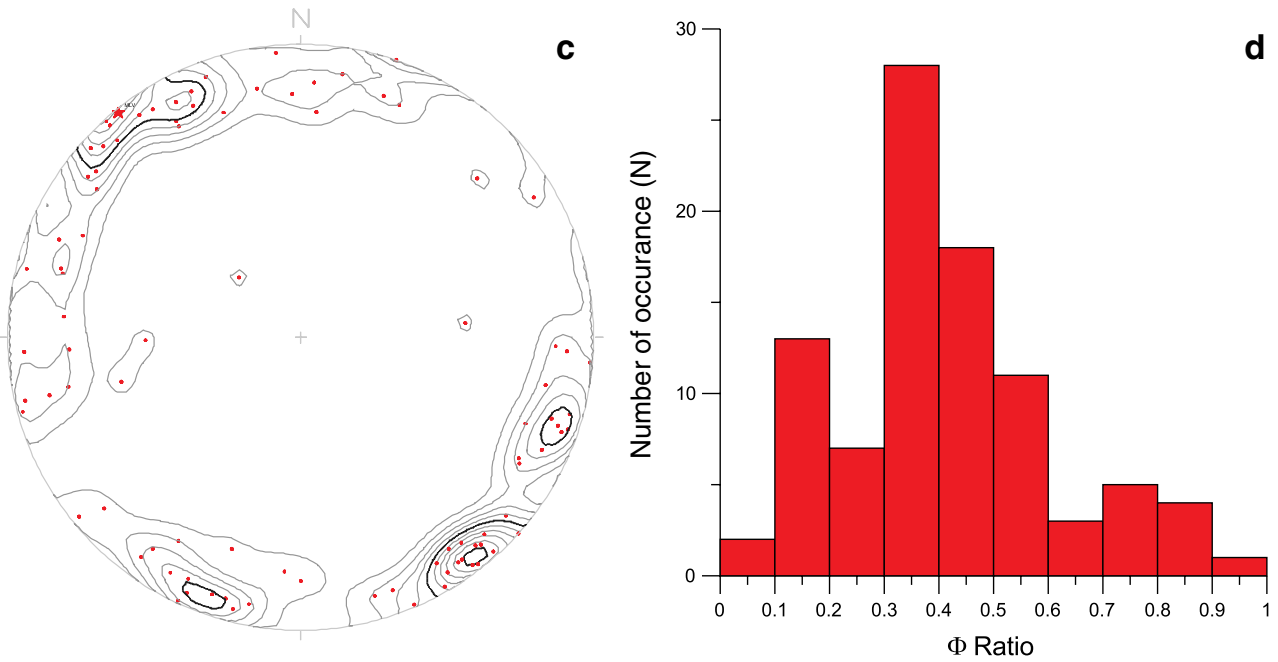

Fig. 17 Density diagrams (a-c) for principle stress orientations $\left(\sigma_{1}, \sigma_{2}\right.$ and $\sigma_{3}$, respectively) and $\mathbf{d}$ frequency distribution of $\Phi$ values for all data. Note that $\sigma_{1}$ is clearly (sub-) vertical while $\sigma_{2}$ and $\sigma_{3}$ orientations are horizontal

\section{Discussion}

\section{Yalvaç Basin evolution}

Our sedimentological results show that the modern margins of the basin represent the paleomargins, sediments of the Yalvaç Basin are fining basinwards, with the clearest depocentre represented by the fine-grained lacustrine Yarıkkaya Formation. In addition, the fining-upwards trend in the lower to middle part of the stratigraphy suggests that most of the accommodation space was formed in the period towards the deposition of the Yarıkkaya Formation, which according to the biostratigraphic interpretations listed above is of Middle Miocene age; the onset of sedimentation in the basin is not known precisely, but must have occurred during or before the Middle Miocene. This age is also supported by the radiometric age determinations from different volcanic levels of the Sille
Fig. 18 (a) Spatial distribution and minor stress $\left(\sigma_{3}\right)$ orientations (black arrows) shown on a structural map of the study area. Structures in light grey are inferred from remotely sensed data. Numbers refer to sampling sites. Red arrows indicate strike-slip solutions. Note that minor stresses tend to be orthogonal to nearby major faults. Rectangles indicate detailed maps shown in $\mathbf{b}$ and $\mathbf{c}$

$(\sim 11.9-11.7 \mathrm{Ma})$ and Afyon ( 8-14.8 Ma) volcanics (Koç et al. 2012; Besang et al. 1977; Keller and Villari 1972).

The presence of thick coarse clastic deposits along the north-western normal fault controlled margin, together with the onlap geometry of the Yarıkkaya Formation onto the basement in the northeast margin of the basin, indicates that the onset of basin subsidence was likely extensioncontrolled, with NE-SW directed extension dominating the major basin-bounding structures. The Yalvaç Basin developed as a half-graben, although we documented NE-SWoriented antithetic normal faults along the west side of the 


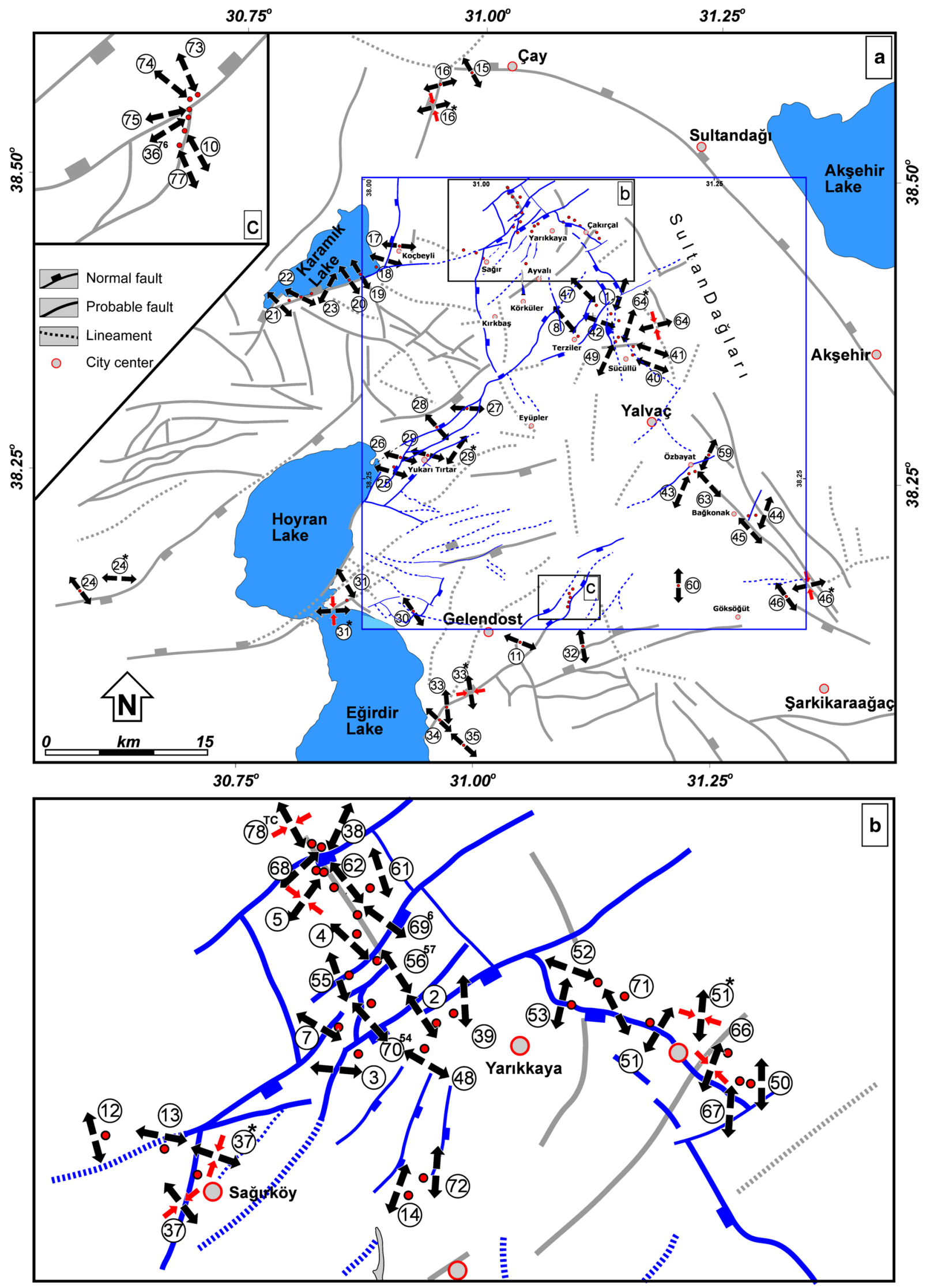




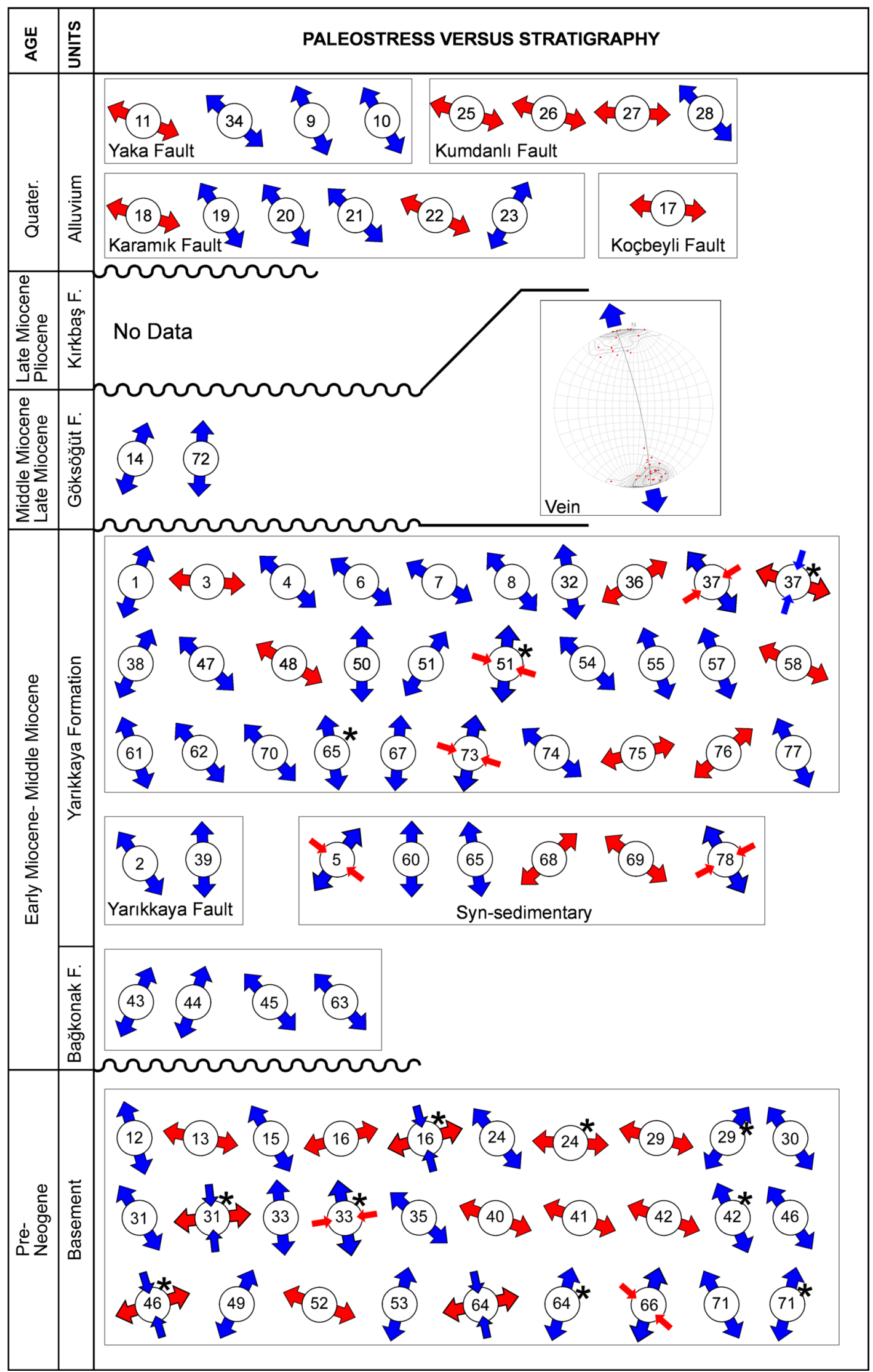


4 Fig. 19 Diagram showing evolution of paleostresses with time, with minor stress $\left(\sigma_{3}\right)$ orientations shown as red and blue arrows. Numbers refer to sampling sites shown in Fig. 18. Red and blue arrows are used to indicate roughly $\mathrm{E}-\mathrm{W}$ and $\mathrm{N}-\mathrm{S}$ extension directions. Note that extension directions change from $\mathrm{E}-\mathrm{W}$ to $\mathrm{N}-\mathrm{S}$

basin (Kumdanlı and Yaka Fault Zones), which may be northern extent of the Fethiye-Burdur Fault Zone.

The Yalvaç Basin is thus a rather local basin with its own depocentre and faulted basin margins. Its formation, however, is not an isolated event. A similar stratigraphy and basin geometry were reported for Altınapa and Akşehir Basin in the east of the study area (Koç et al. 2012; Koçyiğit and Özacar 2003; Koçyiğit et al. 2000). The Altınapa Basin stratigraphy contains volcanoclastic sediments intercalating with lacustrine limestones, which were dated with ${ }^{40} \mathrm{Ar} /{ }^{39} \mathrm{Ar}$ geochronology at $\sim 11.9-11.7 \mathrm{Ma}$ (i.e. upper Middle Miocene). Similarly, the Akşehir Basin contains continental fluviolacustrine sediments with some reworked pumice levels. Saraç (2003), and Koçyiğit et al. (2000) reported micro-mammal localities, which correspond to different stratigraphic horizons of alluvial-fluvial as well as lacustrine deposits, and found that the oldest age obtained from the Akşehir Basin is Early Miocene (MN2 Zone).

Our results from the Yalvaç Basin further demonstrate that throughout the basin history, extension has remained active and was multi-directional although $\mathrm{E}-\mathrm{W}$ and $\mathrm{N}-\mathrm{S}$ extension slightly dominated. The main basin-bounding structures (Çakırçal and Sağır Fault Zones) are determined by $\sim \mathrm{N}-\mathrm{S}$ striking normal faults in response to $\mathrm{E}-\mathrm{W}$ stretching, but subordinate, yet prominent $\sim \mathrm{E}-\mathrm{W}$ trending (Yarıkkaya, Kumdanlı and Yaka Fault Zones), dip-slip normal faults in response to $\sim \mathrm{N}-\mathrm{S}$ extension have continuously played a role as well. Similar structural records were also reported by Yağmurlu (1991b). He suggested that these fault zones were inherited from pre-Neogene N-S compressional deformation and were activated during Middle Miocene extension. Yağmurlu (1991b) is also suggested that the basin was subjected to firstly compressional and then extensional tectonics during the Pliocene, indicating the strike-slip deformation of the Kumdanlı Fault Zone as evidence for the compression. However, our stress inversion results of the fault-slip measurements collected along the Kumdanlı Fault Zone (Fig. 14) show that its motions are consistent with basin extension. Koçyiğit et al. (2012) concluded that extension shaped the Yalvaç Basin, interrupted by a short-term contractional phase. They claimed that the Yarıkkaya Formation was deformed by this short compressive tectonic episode. The field observations presented in Koçyiğit et al. (2012) and also in our study show that folds developed in the Yarıkkaya Formation are only very gentle (interlimb angles are between $180^{\circ}$ and $120^{\circ}$ ). This type of undulations can easily develop during extension al tectonic regime (Schlische 1995). Janecke et al. (1998) reported that the interlimb angle of the extensional folds can range from $\sim 100^{\circ}$ up to $175^{\circ}$ (open to gentle folds). We therefore see no evidence to suggest that compressional tectonics have played a role in the deformation history of the Yalvac Basin since the Middle Miocene.

Active seismicity (Fig. 2) demonstrates that the multidirectional extension that we documented from the basin's stratigraphy remains active today, and we therefore conclude that the modern extensional tectonic regime in the core of the Isparta Angle started at least $\sim 12 \mathrm{Ma}$ ago, and likely several My before, to account for the stratigraphy deposited in the Yalvaç and Altınapa Basins below the oldest dated deposits.

\section{Regional implications}

These results cast an interesting light on the discussion regarding the causes of $\mathrm{E}-\mathrm{W}$ shortening in the centre of the Isparta Angle along the Aksu Thrust (Poisson 1977; Poisson et al. 2003), as well as offshore in the Bay of Antalya (Hall et al. 2014), which has been active from Early-Middle Miocene to at least Pliocene times. Both E-W extension and E-W shortening in the Isparta Angle region are surprising given the plate tectonic setting dominated by $\mathrm{N}-\mathrm{S}$ convergence of Africa and Eurasia. Some authors suggested that the Aksu Thrust is caused by the westwards escape of Anatolia along the North Anatolian fault that is believed to be triggered by the collision between Arabia and Eurasia in eastern Anatolia (e.g. Glover and Robertson 1998; Poisson et al. 2003; Deynoux et al. 2005; Hall et al. 2014). This scenario may be inspired by the broadly similar age inferred for this collision $(\sim 10-13 \mathrm{Ma})$ based on stratigraphic and volcanological-geochemical data, and uplift and exhumation ages in the collision zone (Şengör et al. 2003; Keskin 2003; Faccenna et al. 2006, 2014; Hüsing et al. 2009; Okay et al. 2010).

Our results, however, cast doubt on the validity of this mechanism. Although the westwards escape of Anatolia relative to Eurasia is unequivocal (e.g. Şengör et al. 2005; Reilinger et al. 2010), the E-W extension in the eastern limb of the Isparta Angle demonstrates that shortening to the west, in the heart of the Isparta Angle, cannot be caused by a push driven by Arabia-Anatolia collision in the east. Similarly, the E-W late Miocene-Pliocene shortening in the heart of the Isparta Angle, as documented along the Aksu thrust as well as farther south in the offshore Antalya Basin (Poisson et al. 2003; Hall et al. 2014) demonstrates that extension in the eastern limb of the Isparta Angle cannot be driven by Aegean extension. In addition, Aegean extension is directed NNE-SSW (van Hinsbergen and Schmid 2012). 
Geological records suggesting NE-SW extension, such as in Western Greece, are formed by rocks that also underwent NNE-SSW extension, but subsequently rotated clockwise (van Hinsbergen et al. 2005; van Hinsbergen and Schmid 2012); similarly, extension directions in the west Anatolian part of the Aegean back-arc (i.e. the Menderes Massif) that are currently indicating $\mathrm{N}-\mathrm{S}$ extension in the middle Miocene also formed due to NNE-SSW extension, but rotated counterclockwise (van Hinsbergen et al. 2010a, b). Even if $\mathrm{E}-\mathrm{W}$ shortening in the heart of the Isparta Angle is ignored, the E-W to NE-SW extension direction in central Anatolia is hard to explain by rollback of the Aegean slab. A history of Early to Middle Miocene NE-SW extension and NW-SE extension was recently documented in the Lycian Nappes to the west of the Aksu thrust (Alçiçek and ten Veen 2008; Alçiçek et al. 2013). This history of extension, however, is synchronous with and occurs in the hanging wall of a top-to-the-southeast thrust that brings the Lycian nappes over the Bey Dağları platform (Hayward 1984; van Hinsbergen et al. 2010a), likely as a result of gravitational sliding (van Hinsbergen 2010). This extension history is restricted to the Lycian nappes and did not affect the Bey Dağları foreland, or the Menderes hinterland, and in addition, the bulk of deformation is accomplished by $15 \mathrm{Ma}$, i.e. predating most of the history in our study area.

The simultaneous activity of E-W shortening in the centre of the Isparta Angle and E-W extension $\sim 100 \mathrm{~km}$ therefore requires a dynamic explanation on the scale of the Isparta Angle. Flecker et al. (2005) suggested that southwards rollback of the Cyprus slab may have driven extensional basin formation in our study area. Although this mechanism is successful in explaining the $\mathrm{N}-\mathrm{S}$ extension component that we found in the Yalvac basin and that we previously documented in the Altınapa Basin (Koç et al. 2012), it cannot explain the E-W extension that simultaneously dominated the basin formation history in the study area. Van Hinsbergen et al. (2010a, b) argued that the E-W shortening along the Aksu Thrust is the result of strain partitioning of transpression along the Kırkkavak and Aksu Faults that accommodated counterclockwise rotation of the Bey Dağları platform and overlying Lycian Nappes relative to central Anatolia between $\sim 15$ and $5 \mathrm{Ma}$. Although this mechanism may explain the shortening in the centre of the Isparta Angle, it is insufficient to explain the E-W extension along the eastern limb of the Isparta Angle.

A successful explanation for the kinematic history of the Isparta Angle since at least the middle Miocene thus explains local convergence in the heart of the Isparta Angle while at the same time explains $(\mathrm{N}) \mathrm{E}-(\mathrm{S}) \mathrm{W}$ extension the eastern Isparta Angle limb, alongside N-S extension that can be explained by southwards retreat of the Cyprus slab (Flecker et al. 2005). Interestingly, seismic tomographic images of the mantle below the Isparta Angle published by de Boorder et al. (1998) and later, in more detail, Biryol et al. (2011), as well as a study focused on earthquake hypocentres in the mantle below the study area (Kalyoncuoğlu et al. 2011), have shown that there are two separate slab segments below southern Turkey: a northwards dipping slab below Cyprus, which in most of the upper mantle can be tomographically discerned from an eastwards dipping, $\mathrm{N}-\mathrm{S}$ striking slab, and associated Benioff zone below the Isparta Angle and Antalya Bay (Biryol et al. 2011; Kalyoncuoğlu et al. 2011), which we call the Antalya slab. Seismic tomographic images of van Hinsbergen et al. (2010c) and Biryol et al. (2011) clearly show that the Antalya slab is disconnected from the Aegean slab along a prominent transform (STEP, Govers and Wortel 2005). Biryol et al. (2011) and Schildgen et al. (2012a) suggested that the Antalya slab is a fragment of the Cyprus slab that for some reason rotated into a $\mathrm{N}-\mathrm{S}$ orientation. Instead, we suggest that the thrust that the Antalya slab formed as a result of a separate, $\mathrm{N}-\mathrm{S}$ striking subduction zone, that dips eastwards and until at least Pliocene time connected to the surface along the Aksu thrust and its offshore equivalents, with Bey Dağları in the lower plate, and the Taurides in the upper plate. This narrow slab fragment, experiencing westwards trench retreat, would create overriding plate extension consistent with the basin evolution documented in this paper and in Koç et al. (2012), as well as the shortening documented in the heart of the Isparta Angle.

Recently, Lefebvre et al. (2013) and Advokaat et al. (2014) showed that in Late Cretaceous time, a N-S trending subduction system must have existed in central Anatolia below the Kursehir block, which drove E-W overriding plate extension that exhumed the Kirsehir high-grade metamorphic massif and created supra-detachment sedimentary basins. The modern slab below the Isparta Angle may well have started along this Cretaceous $\mathrm{N}-\mathrm{S}$ trending subduction segment and rolled back westwards accreting the Tauride fold-thrust belt at the front and extending the overriding plate throughout the Late Cretaceous and Paleogene in the rear. This may explain the NE-SW to E-W extension dominating the evolution and subsidence of the, Tuzgölü Basin, as shown by seismic reflection profiles (Çemen et al. 1999; Fernandez-Blanco et al. 2013) and geological studies (Dellaloglu and Aksu 1984; Fernandez-Blanco et al. 2013; Özsayin et al. 2013). The locus of E-W extension appears to migrate westwards through central Anatolia with time, and following their extension, become shortened in a N-S direction again, first in the Kırsehir massif and Ulukısla basins in Eo-Oligocene times (e.g. Clark and Robertson 2002, 2005; Gülyüz et al. 2013; Advokaat et al. 2014), and in Middle Miocene in Çankırı Basin (Kaymakci et al. 2000, 2001a, b, 2003), and Late Miocene time also in the Tuzgolu Basin (until 6.8 Ma, Özsayin et al. 2013). We have no evidence that $\mathrm{N}-\mathrm{S}$ shortening has affected our study area yet 
and conclude that the causes of this compression should be restricted to an area east of the Western Taurides, for instance, induced by collision of Cyprus with Turkey reflected in late Miocene shortening of the Kyrenia range (e.g. Schildgen et al. 2012a; McCay and Robertson 2013).

Many studies of the Cretaceous evolution of Anatolia have called for complex subduction zone configurations with multiple subduction zones, micro-plates and triple junctions accommodating Africa-Europe convergence (e.g. Robertson et al. 2003, 2013; Robertson and Ustaömer 2011). Our study suggests that the modern subduction zone configuration of central and eastern Anatolia, as portrayed by seismic tomographic images and documented through bidirectional extension direction documented here, may be more complex than widely assumed. We suggest that the segmented Africa-Europe plate boundary, with separate Aegean, Antalya, and Cyprus slabs at high angles to each other, is inherited from Anatolia's complex geodynamic and plate kinematic history that preceded today's snapshot. The rather complex geometry of slabs below the study area was recently taken into account by Schildgen et al. (2012a) to explain the uplift history of southern Anatolia in latest Miocene and Pliocene time, which recently has received wide attention (e.g. Deynoux et al. 2005; Cosentino et al. 2012; Schildgen et al. 2012a, b, 2014). These authors inferred that the disconnection between the Aegean, Antalya, and Cyprus slab segments may have led to asthenospheric inflow and resulted dynamic topographic effects. Our study suggests that in addition to any dynamic topography, the Antalya slab has had an important contribution to the kinematic evolution of the Isparta Angle in Mio-Pliocene, and even modern times. This recent deformation may also have significantly contributed to the uplift history of the Taurides since the late Miocene.

\section{Conclusions}

In this paper, we study the stratigraphic, sedimentological and structural evolution of the Middle Miocene and younger Yalvaç Basin, located in the centre of the Isparta Angle. The Yalvaç Basin unconformably covers a composite basement consisting of ophiolites, metamorphic rocks of the Afyon zone, and non-metamorphic rocks of the Tauride fold-thrust belt that were thrust in Cretaceous to Eocene time. A fining-upwards succession of basal conglomerates into the Middle Miocene Yarıkkaya Formation consisting of fine lacustrine limestones, and clays illustrate that most of the accommodation space was formed during the Middle Miocene or shortly before. Interfingering of the Yarıkkaya Formation with marginal clastic deposits towards the modern basement ridges surrounding the basin shows that the basin was restricted to its modern dimension and represented a local depocentre.

Initial subsidence was dominated by approximately $\mathrm{NW}-\mathrm{SE}$ to $\mathrm{N}-\mathrm{S}$ trending basin-bounding faults in the east that produced half-graben geometry of the Yalvaç Basin, with minor antithetic faults in the west. Although the dominant extension was NE-SW to E-W, subordinate NW-SE to E-W striking normal faults are shown to have been simultaneously active throughout the history of the basin. We confirm this conclusion by extensive paleostress analysis using outcrop-scale growth faults and vein sets in the basin's stratigraphy, and a similar history was recently documented from the Altınapa Basin $\sim 100 \mathrm{~km}$ to the southeast of the Yalvaç Basin. This multi-directional extension remains active today as shown by recent seismicity. We therefore conclude that the modern extensional regime in the eastern limb of the Isparta Angle has likely been active since at least Middle Miocene times.

In Middle Miocene to Pliocene time, E-W shortening was accommodated along the Aksu Thrust, and offshore within the Bay of Antalya in the heart of the Isparta Angle, $\sim 100 \mathrm{~km}$ to the west of the study area. The E-W extension in the Yalvac and Altınapa Basins renders a causal relationship of this shortening with westwards escape of Anatolia unlikely. Instead, our results call for an as yet unidentified regional geodynamic cause for the simultaneous E-W shortening in the centre, and E-W extension in the eastern limb of the Isparta Angle.

Acknowledgments Research for this paper occurred within the context of the Netherlands Research School of Integrated Solid Earth Sciences (ISES) and was supported by ÖYP research fund of Turkish Government (No: BAP-08-11-DPT.2002K120510) and DARIUS programme. DJJvH acknowledges ERC Starting Grant number 306810 (SINK) and an NWO VIDI grant. Hasan Kocatepe, M. Onur Öztepe, Kemal Koç and Kadir Öztepe are acknowledged for their assistance during fieldwork in 2011 and 2012.

\section{References}

Advokaat EL, van Hinsbergen DJJ, Kaymakcı N, Vissers RLM, Hendriks BWH (2014) Late Cretaceous extension and Palaeogene rotation-related contraction in Central Anatolia recorded in the Ayhan-Büyükkışla basin. Int Geol Rev. doi:10.1080/00206814 .2014 .954279

Alçiçek MC, ten Veen JH (2008) The late Early Miocene Acıpayam piggy-back basin: refining the last stages of Lycian nappe emplacement in SW Turkey. Sed Geol 208:101-113

Alçiçek MC, Brogi A, Capezzuoli E, Liotta D (2013) Superimposed basin formation during Neogene-Quaternary extensional tectonics in SW-Anatolia (Turkey): insights from the kinematics of the Dinar Fault Zone. Tectonophysics 608:713-727. doi:10.1016/j.tecto.2013.08.008

Altıner D, Yılmaz İÖ, Özgül N, Akçar N, Bayazitoğlu M, Gaziulusoy ZE (1999) High resolution sequence stratigraphic correlation in the Upper Jurassic (Kimmeridgian)-Upper Cretaceous 
(Cenomanian) peritidal carbonate deposits (Western Taurides, Turkey). Geol J 34:139-158

Andrew T, Robertson AH (2002) The Beyşehir-Hoyran-Hadim Nappes: genesis and emplacement of Mesozoic marginal and oceanic units of the northern Neotethys in southern Turkey. J Geol Soc 159:529-543

Angelier J (1990) Inversion of field data in fault tectonics to obtain the regional stress-III. A new rapid direct inversion method by analytical means. Geophys J Int 103:363-376

Angelier J (1994) Fault slip analysis and paleostress reconstruction. In: Hancock PL (ed) Continental deformation. Pergamon Press, Oxford, pp 53-101

Besang C, Eckhart FJ, Harre W, Kreuzer G, Muller P (1977) Radiometrische Alterbestimmung am neogenen Eruptivgesteinen der Türkei. Geol Jb 25:3-36

Biryol CB, Beck SL, Zandt G, Özacar AA (2011) Segmented African lithosphere beneath the Anatolian region inferred from teleseismic P-wave tomography. Geophys J Int 184:1037-1057. doi:10.1111/j.1365-246X.2010.04910.x

Blumenthal MM (1963) Le système structural du Taurus sud Anatolies. Bull Soc Géol Fr Livre à Mémoire de Professor P Fallot Mémoir hors-série 1:611-662

Carey E, Burinier B (1974) Analyse théorique et numérique d'un modèle mécanique élémentaire appliqué à l'étude d'une population de failes. Comptes Rendus Acadademie Science D279:891-894

Çemen İ, Göncüoglu MC, Dirik K (1999) Structural evolution of the Tuzgölü Basin in Central Anatolia, Turkey. J Geol 107(6). doi:10.1086/314379

Çiftçi NB, Bozkurt E (2007) Anomalous stress field and active breaching at relay ramps: a field example from Gediz Graben, SW Turkey. Geol Mag 144:687-699

Çiner A, Karabiyikoglu M, Monod O, Deynoux M, Tuzcu S (2008) Late Cenozoic sedimentary evolution of the Antalya Basin, Southern Turkey. Turk J Earth Sci 17:1-41

Clark M, Robertson AHF (2002) The role of the Early Tertiary Ulukisla Basin, southern Turkey, in suturing of the Mesozoic Tethys ocean. J Geol Soc 159:673-690

Clark M, Robertson AHF (2005) Uppermost Cretaceous-Lower Tertiary Ulukışla Basin, south-central Turkey: sedimentary evolution of part of a unified basin complex within an evolving Neotethyan suture zone. Sed Geol 173:15-51

Collins AS, Robertson AHF (1997) Lycian melange, southwestern Turkey: an emplaced Late Cretaceous accretionary complex. Geology 25:255-258

Collins AS, Robertson AHF (1998) Processes of Late Cretaceous to Late Miocene episodic thrust-sheet translation in the Lycian Taurides, SW Turkey. J Geol Soc London 155:759-772

Collins AS, Robertson AHF (2003) Kinematic evidence for Late Mesozoic-Miocene emplacement of the Lycian Allochthon over the Western Anatolide Belt, SW Turkey. Geol J 38(3-4):295-310

Cosentino D, Schildgen TF, Cipollari P, Faranda C, Gliozzi E, Hudackova N, Lucifora S, Strecker MR (2012) Late Miocene surface uplift of the southern margin of the Central Anatolian Plateau, Central Taurides, Turkey. Geol Soc Am Bull 124(12):133-145. doi:10.1130/B30466.1

de Boorder H, Spakman W, White SH, Wortel M (1998) Late Cenozoic mineralization, orogenic collapse and slab detachment in the European Alpine Belt. Earth Planet Sci Lett 164(3):569-575

Dellaloglu A, Aksu R (1984) Kulu-Sereflikochisar-Aksaray dolayinin jeolojisi ve petrol olanaklari. Unpubl. TPAO rep. no. 2020

Demirkol C (1982) Yalvaç-Akşehir dolayının stratigrafisi ve Batı Toroslarla deneştrimi. TMMOB Jeoloji Mühendisliği Dergisi 14:3-14

Deynoux M, Çiner A, Karabiyıkoğlu M, Monod O, Manatschal G, Tuzcu S (2005) Facies architecture and depositional evolution of alluvial fan to fan-delta complexes in the tectonically active Miocene Köprüçay Basin, Isparta Angle, Turkey. Sed Geol 173:289-317

Dumont JF, Kerey IE (1975) Eğridir gölü güneyinin temel jeolojik etüdü. Bull Geol Soc Turk 18:163-174

Dunne WM, Hancock PL (1994) Paleostress analysis of small-scale brittle structures. In: Hancock PL (ed) Continental deformation. Pergamon Press, Oxford, pp 101-120

Eren Y (1993) Eldeş-Derbent-Tepeköy-Söğütözü arasının jeolojisi. $\mathrm{PhD}$ Thesis, S.Ü. Fen Bil. Enst. Konya, Turkey, pp 224

Eren Y (1996) Ilgın-Sarayönü (Konya) güneyinde Bozdağlar Masifinin yapısal özellikleri. Geol Bull Turk 39:49-64

Ergin M, Aktar M, Özalaybey S, Tapirdamaz MC, Selvi O, Tarancioglu A (2009) A high-resolution aftershock seismicity image of the 2002 Sultandağ 1 -Çay earthquake $(\mathrm{Mw}=6.2)$. Turkey. J Seismol 13:633-646

Etchecopar A, Vasseur D, Daignières M (1981) An inverse problem in microtectonics for determination of stress tensors from faults striation analysis. J Struct Geol 3:51-65

Faccenna C, Bellier O, Martinod J, Piromallo C, Regard V (2006) Slab detachment beneath eastern Anatolia: a possible cause for the formation of the North Anatolian fault. Earth Planet Sci Lett 242:85-97

Faccenna C, Becker TW, Auer L, Billi A, Boschi L, Brun JP, Capitanio FA, Funiciello F, Horvàth F, Jolivet L, Piromallo C, Royden L, Rossetti F, Serpelloni E (2014) Mantle dynamics in the Mediterranean. Rev Geophys 52. doi:10.1002/2013RG000444

Fernandez-Blanco D, Bertotti G, Çiner A (2013) Cenozoic tectonics of the Tuz Gölü Basin (Central Anatolia Plateau, Turkey. In: Çiner A, Strecker M. Bertotti G (eds) Late Cenozoic evolution of the Central Anatolia Plateau. J Earth Sci 22:715-738

Flecker R, Poisson A, Robertson AHF (2005) Facies and palaeogeographic evidence for the Miocene evolution of the Isparta Angle in its regional eastern Mediterranean context. In: Kelling G, Robertson AHF, Vanbuchen F (eds) Cenozoic sedimentary basins of South Central Turkey. Sedim Geol 173:277-314

Fürst M (1955) Yarıkkaya (Yalvaç) linyit zuhurları hakkında rapor. MTA Rapor No: 2430. Unpublished

Glover C, Robertson AHF (1998) Neogene intersection of the Aegean and Cyprus arcs: extensional and strike-slip faulting in the Isparta Angle, SW Turkey. Tectonophysics 298:103-132

Göğer E, Kıral K (1969) Kızı̈ören dolayının Jeolojisi. M.T.A. rapor no: 5204

Göktunalı K (1957) Yarıkkaya bölgesi linyitli Neojen'in jeolojik etüdü. MTA Rapor No: 2976 (yayımlanmamış.), Ankara

Govers R, Wortel MJR (2005) Lithosphere tearing at STEP faults: response to edges of subduction zones. Earth Planet Sci Lett 236:505-523

Gülyüz E, Kaymakci N, Meijers MJM, van Hinsbergen DJJ, Lefebvre C, Vissers RLM, Hendriks BWH, Peynircioğlu AA (2013) Late Eocene evolution of the Çiçekdağı Basin (central Turkey): Synsedimentary compression during microcontinent-continent collision in central Anatolia. Tectonophysics 602:286-299

Hall J, Aksu AE, King H, Gogacz A, Yaltırak C, Çifçi G (2014) Miocene-Recent evolution of the western Antalya Basin and its linkage with the Isparta Angle, eastern Mediterranean. Mar Geol 349:1-23

Hayward AB (1984) Miocene clastic sedimentation related to the emplacement of the Lycian Nappes and the Antalya Complex SW Turkey. Geol Soc Lond Spe Publ 17:287-300

Homberg C, Hu JC, Angelier J, Bergerat F, Lacombe O (1997) Characterization of stress perturbations near major fault zones: insights from field studies (Jura Mountains) and numerical modelling. J Struct Geol 19:703-718

Hüsing SK, Zachariasse WJ, van Hinsbergen DJJ, Krijgsman W, Inceöz M, Harzhauser M, Mandic, Kroh A (2009) 
Oligo-Miocene foreland basin evolution in SE Anatolia: constraints on the closure of the eastern Tethys gateway. In: van Hinsbergen DJJ, Edwards MA, Govers R (eds) Collision and collapse at the Africa-Arabia-Eurasia subduction zone. Geol Soc Lond Spec Publ 107-132

Janecke US, Vandenburg JC, Blankenau JJ (1998) Geometry, mechanisms and significance of extensional folds from examples in the Rocky Mountain Basin and Range province, U.S.A. J Struct Geol 20:841-856

Kalyoncuoğlu ÜY, Elitok Ö, Dolmaz MN, Anadolu NC (2011) Geophysical and geological imprints of southern Neotethyan subduction between Cyprus and the Isparta Angle, SW Turkey. J Geodyn 52(1):70-82. doi:10.1016/j.jog.2010.12.001

Kaymakci N (2006) Kinematic development and paleostress analysis of the Denizli Basin (Western Turkey): implications of spatial variation of relative paleostress magnitudes and orientations. $\mathbf{J}$ Asian Earth Sci 27:207-222

Kaymakci N, White SH, van Dijk PM (2000) Paleostress inversion in a multiphase deformed area: kinematic and structural evolution of the Çankiri Basin (central Turkey), Part 1. In: Bozkurt E, Winchester JA, Piper JAD (eds) Tectonics and Magmatism in Turkey and the Surrounding area. Geol Soc Lond Spec Publ 173:445-473

Kaymakci N, Ozçelik Y, White SH, van Dijk PM (2001a) Neogene Tectonics of the Çankiri Basin (north Central Turkey). Turkiye Petrol Jeologlari Dernegi Bült 13(1):27-56

Kaymakci N, De Bruijn H, White SH, Van Dijk M, Saraç G, Unay E (2001b) Tectonic implications of the Neogene stratigraphy of the Çankiri basin with special reference to the Çandir locality (North-Central Anatolia, Turkey). In Güleç E, Begun DR, Geraads D (eds) Geology and Vertebrate Paleontology of the Miocene hominoid locality of Çandir. Courier Forschungsinstitut Senckenberg 240:9-28

Kaymakci N, White SH, van Dijk PM (2003) Kinematic and structural development of the Çankiri Basin (Central Anatolia, Turkey). a paleostress inversion study. Tectonophysics 364:85-113

Kaymakci N, Inceöz M, Ertepinar P, Koç A (2010) Late Cretaceous to recent kinematics of SE Anatolia (Turkey). In: Sosson M, Kaymakci N, Stephanson R, Bergarat F, Storatchenoko V (eds) Sedimentary basin tectonics from the Black Sea and Caucasus to the Arabian Platform, vol 340. Geological Society, London, Special Publication, pp 409-435

Keller J, Villari L (1972) Rhyolithic Ignimbrites in the region of Afyon (Central Anatolia). Bull Volcanol 36:342-358

Keskin M (2003) Magma generation by slab steepening and breakoff beneath a subduction-accretion complex: an alternative model for collision-related volcanism in Eastern Anatolia, Turkey. Geophys Res Lett 30(24):8046. doi:10.1029/2003GL018019

Kleinspehn KL, Pershing JC, Teyssier C (1989) Paleostress stratigraphy: a new technique for analyzing tectonic control on sedimentary-basin subsidence. Geology 17:253-256

Koç A, Kaymakci N, van Hinsbergen DJJ, Kuiper KF, Vissers RLM (2012) Tectono-Sedimentary evolution and geochronology of the Middle Miocene Altmapa Basin, and implications for the Late Cenozoic uplift history of the Taurides, southern Turkey. Tectonophysics 532-535:134-155

Koçyiğit A, Özacar AA (2003) Extensional Neotectonic Regime through the NE edge of the outer Isparta Angle, SW Turkey: new field and seismic data. Turk J Earth Sci 12:67-90

Koçyiğit A, Ünay E, Saraç G (2000) Episodic graben formation and extensional neotectonic regime in west central Anatolia and the Isparta Angle: a case study in the Akşehir-Afyon Graben, Turkey. Geol Soc Lond Spec Publ 173:405-421

Koçyiğit A, Gürboğa Ş, Kalafat D (2012) Nature and onset age of neotectonic regime in the northern core of Isparta Angle, SW Turkey. Geodin Acta 25(1-2):52-85
Lahn E (1940) Aksaray-Konya-Isparta mıntıkasının jeolojik hülasas1. MTA Derleme rapor no: 1240. Unpublished

Larsen PH (1988) Relay structures in a Lower Permian basement involved extension system, East Greenland. J Struct Geol 10:3-8

Lefebvre C, Meijers MJM, Kaymakci N, Peynircioğlu A, Langereis CG, van Hinsbergen DJJ (2013) Reconstructing the geometry of central Anatolia during the late Cretaceous: large-scale Cenozoic rotations and deformation between the Pontides and Taurides. Earth Planet Sci Lett 336:83-98

Lillesand M, Keifer RW (1999) Remote sensing and image interpretation, 4th edn. Wiley, USA

McCay GA, Robertson A (2013) Upper Miocene-Pleistocene deformation of the Girne (Kyrenia) Range and Dar Dere (Ovgos) lineaments, northern Cyprus: role in collision and tectonic escape in the easternmost Mediterranean region. Geol Soc Lond Spec Publ 372:421-445

McClusky S, Balassanian S, Barka A, Demir C, Ergintav S, Georgiev I, Gurkan O, Hamburger M, Hurst K, Kahle H, Kastens K, Kekelidze G, King R, Kotzev V, Lenk O, Mahmoud S, Mishin A, Nadariya M, Ouzounis A, Paradissis D, Peter Y, Prilepin M, Reilinger R, Sanli I, Seeger H, Tealeb A, Toksöz MN, Veis G (2000) Global Positioning System constraints on plate kinematics and dynamics in the eastern Mediterranean and Caucasus. J Geophys Res 105:5695-5719

Okay AI (1989) Geology of the Menderes Massif and the Lycian Nappes south of Denizli, western Taurides. Miner Resour Explor Bull 109:37-51

Okay AI, Satir M, Maluski H, Siyako M, Monié P, Metzger R, Akyüz S (1996) Paleo- and Neo-Tethyan events in northwest Turkey: geological and geochronological constraints. In: Yin A, Harrison M (eds) Tectonic evolution of Asia. Cambridge University Press, New York, pp 420-441

Okay AI, Zattin M, Cavazza W (2010) Apatite fission-track data for the Miocene Arabia-Eurasia collision. Geology 38:35-38

Özcan A, Göncüoglu MC, Turhan N, Sentürk K, Uysal S, Isik A (1990) Konya-Kadınhanı-Ilgın Dolayının Temel Jeolojisi. MTA Rapor No: 9535

Özkan AM (1998) Konya Batısındakı Neojen Çökellerinin Stratigrafisi ve Sedimantolojisi. PhD Thesis, S.Ü. Fen Bil. Enst., Konya, Türkey, pp 208

Özkan AM, Söğüt AR (1999) Dilekçi (Konya batısı) çevresindeki Neojen çökellerinin stratigrafisi. J Eng Sci 5:1131-1138

Özsayin E, Çiner A, Dirik K, Rojay B, Fernandez-Blanco D, Melnick D, Garcin Y, Bertotti G, Strecker M, Schildgen T, Sudo M (2013) Plio-Quaternary Extensional Tectonics of the Central Anatolian Plateau: A case study from the Tuz Gölü Basin, Turkey. In: Çiner A, Strecker M, Bertotti G (eds) Late Cenozoic Evolution of the Central Anatolia Plateau. J Earth Sci 22:691-714

Peacock DCP, Sanderson DJ (1991) Displacements, segment linkage and relay ramps in normal fault zones. J Struct Geol 13:721-733

Peacock DCP, Sanderson DJ (1994) Geometry and development of relay ramps in normal fault systems. Bull Am Assoc Pet Geol 78:147-165

Pekmezciler S (1958) Yarıkkaya (Isparta vilayeti) linyit aramaları hakkında rapor. MTA Rapor No: 2640. Unpublished

Poisson A (1977) Récherches géologique dans les Taurides occidentales (Turquie) [D.S. thèse]: Université Paris-Sud, Orsay 795 pp

Poisson A, Wernli R, Sagular EK, Temiz H (2003) New data concerning the age of the Aksu Thrust in the south ofthe Aksu valley, Isparta Angle (SW Turkey): consequences for the Antalya Basin and the Eastern Mediterranean. Geol J 38:311-327

Poyraz SA, Pınar A, Özden S, Tunçer MK (2014) Implications of 2007's Earthquake Activity in Eğirdir Lake (SW Anatolia) 
Based on Moment Tensor Solutions and Inversion of Stress State. Pure appl Geophys 171(7):1299-1309. doi:10.1007/ s00024-013-0715-5

Reilinger R, McClusky S, Paradissis D, Ergintav S, Vernant P (2010) Geodetic constraints on the tectonic evolution of the Aegean region and strain accumulation along the Hellenic subduction zone. Tectonophysics 488(1-4):22-30

Robertson AHF, Ustaömer T (2011) Role of tectonic-sedimentary melange and Permian-Triassic cover units, central southern Turkey in Tethyan continental margin evolution. J Asian Earth Sci 40:98-120

Robertson AHF, Poisson A, Akınc1 Ö (2003) Developments in research concerning Mesozoic-Tertiary Tethys and neotectonics in the Isparta Angle, SW Turkey. Geol J 38(3-4):195-234

Robertson AHF, Parlak O, Ustaömer T (2013) Late Palaeozoic-Early Cenozoic tectonic development of Southern Turkey and the easternmost Mediterranean region: evidence from the interrelations of continental and oceanic units. Geol Soc Lond Spec Publ 372(1):9-48. doi:10.1144/SP372.22

Saraç G (2003) Türkiye omurgalı fosil yatakları. Scientific Report No: 10609, General Directorate of the Mineral Research and Exploration of Turkey (MTA), Ankara, pp 208

Schildgen TF, Cosentino D, Caruso A, Buchwaldt R, Yıldırım C, Bowring SA, Rojay B, Echtler H, Strecker MR (2012a) Surface expression of Eastern Mediterranean slab dynamics: neogene topographic and structural evolution of the SW margin of the Central Anatolian Plateau, Turkey. Tectonics 31(2). doi:10.102 9/2011TC003021

Schildgen TF, Cosentino D, Bookhagen B, Niedermann S, Yıldırım C, Echtler H, Wittmann H, Strecker MR (2012b) Multi-phased uplift of the southern margin of the Central Anatolian plateau, Turkey: a record of tectonic and upper mantle processes. Earth Planet Sci Lett 317-318:85-95. doi:10.1016/j.epsl.2011.12.003

Schildgen TF, Yıldırım C, Cosentino D, Strecker MR (2014) Linking slab break-off, Hellenic trench retreat, and uplift of the Central and Eastern Anatolian plateaus. Earth Sci Rev 128:147-168

Schlische RW (1995) Geometry and origin of fault-related folds in extensional settings. Am Assoc Pet Geol Bull 79:1661-1678

Şengör AMC, Özeren S, Genç T, Zor E (2003) East Anatolian high plateau as a mantle-supported, north-south shortened domal structure. Geophys Res Lett 30(24):8045
Şengör AMC, Tüysüz O, Imren C, Sakınç M, Eyidogan H, Görür N, Pichon XL, Rangin C (2005) The North Anatolian Fault: a new look. Annu Rev Earth Planet Sci 33(1):37-112. doi:10.1146/annurev.earth.32.101802.120415

Taymaz T, Tan O, Yolsal S (2004) Seismotectonics of western Turkey: a synthesis of source parameters and rupture histories of Recent earthquakes. EOS Trans AGU 85:47

Tiryakioğlu İ, Floyd M, Erdoğan S, Gülal G, Ergintav S, McClusky S, Reilinger R (2013) GPS constraints on active deformation in the Isparta Angle region of SW Turkey. Geophys J Int 195:1455-1463

van Hinsbergen DJJ (2010) A key extensional metamorphic complex reviewed and restored: the Menderes Massif of western Turkey. Earth Sci Rev 102:60-76

van Hinsbergen DJJ, Schmid SM (2012) Map view restoration of Aegean-West Anatolian accretion and extension since the Eocene: Tectonics, 31, TC 5005. doi:10.1029/2012TC003132

van Hinsbergen DJJ, Langereis CG, Meulenkamp JE (2005) Revision of the timing, magnitude and distribution of Neogene rotations in the western Aegean region. Tectonophysics 396:1-34

van Hinsbergen DJJ, Dekkers MJ, Koç A (2010a) Testing Miocene remagnetization of Bey Dağları: timing and amount of Neogene rotations in SW Turkey. Turk J Earth Sci 19:123-156

van Hinsbergen DJJ, Kaymakci N, Spakman W, Torsvik TH (2010b) Reconciling the geological history of western Turkey with plate circuits and mantle tomography. Earth Planet Sci Lett 297:674-686

van Hinsbergen DJJ, Dekkers MJ, Bozkurt E, Koopman M (2010b) Exhumation with a twist: paleomagnetic constraints on the evolution of the Menderes metamorphic core complex, western Turkey. Tectonics 29(3). doi:10.1029/2009TC002596

Wedding H (1954) Yalvaç'ın şimalinde Yarıkkaya linyit zuhuru hakkında rapor: MTA Rapor No: 2200. Unpublished

Yağmurlu F (1991a) Stratigraphy and depositional environments of Yalvaç-Yarıkkaya Neogene basin, SW-Anatolia. Geol Bull Turk 34:9-19 (In Turkish)

Yağmurlu F (1991b) Yalvaç-Yarıkkaya Neojen havzasının tektonosedimanter özellikleri ve yapısal evrimi. MTA Derg 112:1-13 